\title{
Cold Test Loop Integrated Test Loop Results
}

September 2003

Prepared by

T. J. Abraham

The Providence Group Applied Technologies, Inc.

J. F. Walker, Jr.

Oak Ridge National Laboratory 


\title{
DOCUMENT AVAILABILITY
}

Reports produced after January 1, 1996, are generally available via the DOE Information Bridge.

Web site http://www.doe.gov/bridge

Reports produced before January 1, 1996, may be purchased by members of the public from the following source.

\author{
National Technical Information Service \\ 5285 Port Royal Road \\ Springfield, VA 22161 \\ Telephone 703-605-6000 (1-800-553-6847) \\ TDD 703-487-4639 \\ Fax 703-605-6900 \\ E-mail orders@ntis.fedworld.gov \\ Web site http://www.ntis.gov/ordering.htm
}

Reports are available to U.S. Department of Energy (DOE) employees, DOE contractors, Energy Technology Data Exchange (ETDE) representatives, and International Nuclear Information System (INIS) representatives from the following source.

Office of Scientific and Technical Information

P.O. Box 62

Oak Ridge, TN 37831

Telephone 865-576-8401

Fax 865-576-5728

E-mail reports@adonis.osti.gov

Web site http://www.osti.gov/products/sources.html

This report was prepared as an account of work sponsored by an agency of the United States government. Neither the United States government nor any agency thereof, nor any of their employees, makes any warranty, express or implied, or assumes any legal liability or responsibility for the accuracy, completeness, or usefulness of any information, apparatus, product, or process disclosed, or represents that its use would not infringe privately owned rights. Reference herein to any specific commercial product, process, or service by trade name, trademark, manufacturer, or otherwise, does not necessarily constitute or imply its endorsement, recommendation, or favoring by the United States government or any agency thereof. The views and opinions of authors expressed herein do not necessarily state or reflect those of the United States government or any agency thereof. 
Nuclear Science and Technology Division

\title{
Cold Test Loop Integrated Test Loop Results
}

\author{
T. J. Abraham* \\ J. F. Walker, Jr.
}

Date Published: September 2003

\author{
Prepared by \\ OAK RIDGE NATIONAL LABORATORY \\ Oak Ridge, Tennessee 37831-6283 \\ managed by \\ UT-Battelle, LLC \\ for the \\ U.S. DEPARTMENT OF ENERGY \\ under contract DE-AC05-00OR22725
}

*The Providence Group Applied Technologies, Inc., Knoxville, Tennessee 



\section{CONTENTS}

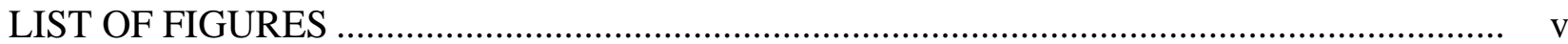

LIST OF TABLES ………............................................................................................ vii

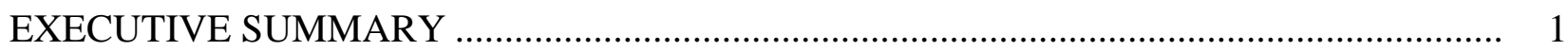

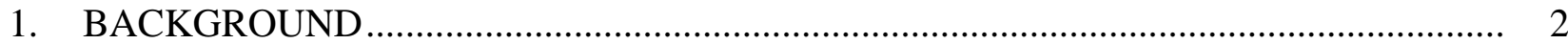

2. DESIGNATION OF CORE TEAM AND KEY RESPONSIBILITIES ............................... 3

3. TEST FACILITY AND SYSTEMS.............................................................................. 3

3.1 THE INTEGRATED TEST LOOP ........................................................................ 3

3.1.1 Surrogate Tank ................................................................................ 5

3.1.2 Slurry and Sluice Pumps .................................................................................. 5

3.1.3 Other Components ........................................................................................... 7

3.2 THE COMPONENT TEST LOOP ........................................................................ 7

3.3 SURROGATE .................................................................................................... 9

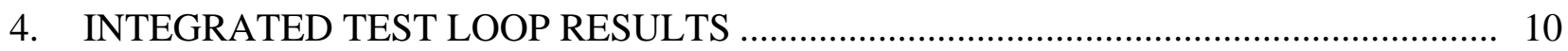

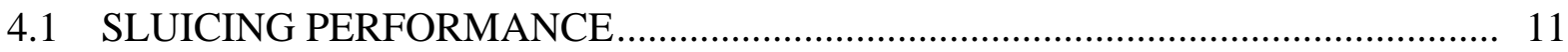

4.1.1 Nozzle and Configuration ............................................................................... 11

4.1.2 Spray Ring Configuration and Operation ....................................................... 12

4.1.3 Pump Performance and Operation ............................................................. 13

4.2 PERFORMANCE OF SOLARTRON UNIT …….................................................... 14

4.3 SOLIDS CONCENTRATION IN THE EFFLUENT ………...................................... 15

4.4 PARTICLE SIZE DISTRIBUTION ………………............................................... 16

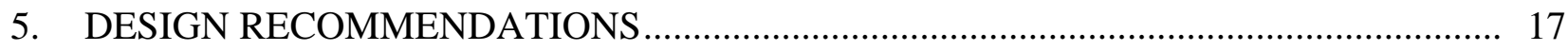

6. RECOMMENDATIONS FOR FUTURE WORK ....................................................... 17

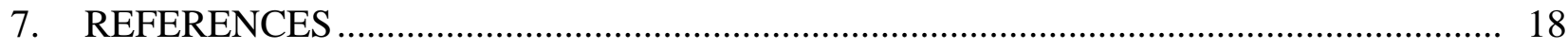

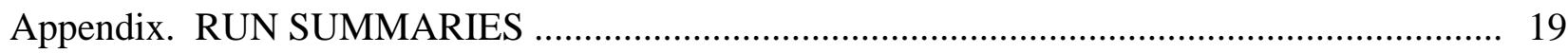





\section{LIST OF FIGURES}

Figure $\quad$ Page

3.1 Piping and instrument diagram for the ITL .................................................... 4

3.2 View of the surrogate tank prior to testing ....................................................... 5

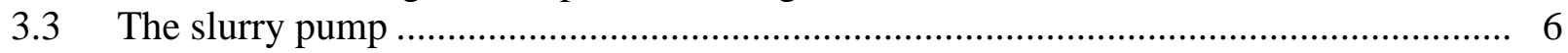

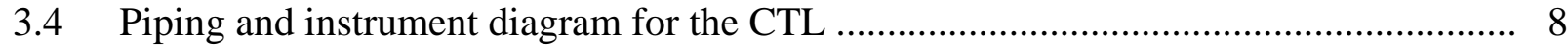

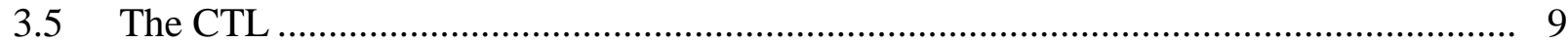

4.1 Comparison of the performance of different nozzle configurations ........................... 11

4.2 Nozzle pattern for the Viper Turbo nozzles ...................................................... 12

4.3 Pump screen after an ITL run with Bentogrout added to the surrogate ........................ 13

A.1 Surrogate tank prior to the start of the ITL-1 series runs ......................................... 22

A.2 Surrogate tank after Run ITL-1-A ....................................................................... 22

A.3 Area just under slurry pump before Run ITL-1-A ................................................. 23

A.4 Area immediately under the slurry pump after Run ITL-1-A ................................... 23

A.5 One of the receiving tanks after Run ITL-1-A .................................................. 24

A.6 Pump load as a function of flow at approximately $670 \mathrm{rpm}$.................................... 30

A.7 Surrogate tank covered with Bentogrout prior to Run ITL-4 ................................... 32

A.8 Surrogate tank covered with Bentogrout after Run ITL-4 ........................................ 33

A.9 Debris added to the surrogate tank for Run ITL-6 ................................................. 35 



\section{LIST OF TABLES}

Table

Page

3.1 Comparison of surrogate and specification requirements...................................... 10

4.1 Summary of solids concentrations in several of the ITL runs prior to Bentogrout ....... 16

4.2 Summary of solids concentrations in Run ITL-4 with Bentogrout........................... 16

A.1 Process data from the ITL Series 1 runs ............................................................. 25

A.2 Analytical data from the ITL Series 1 runs........................................................ 26

A.3 Process data from the ITL Series 2 runs .......................................................... 27

A.4 Analytical data from the ITL Series 2 runs.......................................................... 29

A.5 Process data from the ITL Series 3 runs .............................................................. 31

A.6 Analytical data from the ITL Series 3 runs................................................... 31

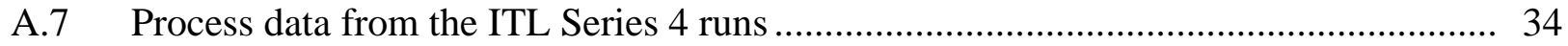

A.8 Analytical data from the ITL Series 4 runs....................................................... 34

A.9 Process data from the ITL Series 6 runs ........................................................... 36

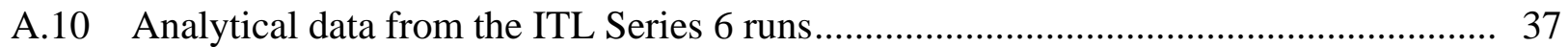

A.11 Process data from the ITL Series 7 runs ........................................................... 38

A.12 Analytical data from the ITL Series 7 runs..................................................... 39 



\section{EXECUTIVE SUMMARY}

A testing facility (Cold Test Loop) was constructed and operated to demonstrate the efficacy of the Accelerated Waste Retrieval (AWR) Project's planned sluicing approach to the remediation of Silos 1 and 2 at the Fernald Environmental Management Project near Cincinnati, Ohio. The two silos contain almost 10,000 tons of radium-bearing low-level waste, which consists primarily of solids of raffinates from processing performed on ores from the Democratic Republic of Congo (commonly referred to as "Belgium Congo ores") for the recovery of uranium. These silos are $80 \mathrm{ft}$ in diameter, $36 \mathrm{ft}$ high to the center of the dome, and $26.75 \mathrm{ft}$ to the top of the vertical side walls.

The test facility contained two test systems, each designed for a specific purpose. The first system, the Integrated Test Loop (ITL), a near-full-scale plant including the actual equipment to be installed at the Fernald Site, was designed to demonstrate the sluicing operation and confirm the selection of a slurry pump, the optimal sluicing nozzle operation, and the preliminary design material balance. The second system, the Component Test Loop (CTL), was designed to evaluate many of the key individual components of the waste retrieval system over an extended run.

The major results of the initial testing performed during July and August 2002 confirmed that the AWR approach to sluicing was feasible. The ITL testing confirmed the following:

- The selected slurry pump (Hazleton 3-20 type SHW) performed well and is suitable for AWR application. However, the pump's motor should be upgraded to a 200-hp model and be driven by a 150-hp variable-frequency drive (VFD). A 200-hp VFD is not much more expensive and would allow the pump to operate at full speed.

- The best nozzle performance was achieved by using 15/16-in. nozzles operated alternately. This configuration appeared to most effectively mine the surrogate.

- The Solartron densitometer, which was tested as an alternative mass flow measurement device, did not operate effectively. Consequently, it is not suitable for application to the AWR process.

- Initially, the spray ring (operated at approximately $2300 \mathrm{psi}$ ) and the nozzles provided by the pump vendor did not perform acceptably. The nozzles were replaced with a more robust model, and the performance was then acceptable.

- The average solids concentration achieved in the slurry before Bentogrout addition was approximately $16 \%$ by weight. The solids concentration of the slurry after Bentogrout addition ranged from $26 \%$ to approximately $40 \%$. The slurry pump and ITL system performed well at every concentration. No line plugging or other problems were noted.

The results of the CTL runs and later ITL testing are summarized in an appendix to this report. 


\section{BACKGROUND}

Operable Unit 4 at the U.S. Department of Energy (DOE) Fernald Environmental Management Project near Cincinnati, Ohio, includes two domed silos that contain almost 10,000 tons of radium-bearing low-level waste. The waste, known as K-65 waste, consists primarily of solids of raffinates from processing operations performed on ores from the Democratic Republic of Congo (commonly referred to as "Belgium Congo ores") for the recovery of uranium. These silos are $80 \mathrm{ft}$ in diameter, $36 \mathrm{ft}$ high to the center of the dome, and $26.75 \mathrm{ft}$ to the top of the vertical side walls. The silos were constructed in 1951 and 1952 of concrete wrapped with steel posttensioning wires, and the sides were covered with gunite. The silos are also equipped with an underdrain system and decant sump tank to collect any potential liquid leakage through the base of the silos. Earthen berms have been placed around the outside silo walls and a radon collection system installed to reduce exposure levels to workers and release to the environment. Details on the construction of the silos and the radon treatment system have been documented in a Fernald report. $^{1}$

Waste materials were originally transferred to Silos 1 and 2 by pumping the wastes in the form of a slurry. The waste solids settled, and the slurry liquid was removed by decant ports located in two vertical lines on diametrically opposed sides of each silo, with the lowest port located $1 \mathrm{ft}$ from the bottom. Silo 1 contains 115,900 $\mathrm{ft}^{3}$ of K-65 waste and 12,600 $\mathrm{ft}^{3}$ of a commercial grade of bentonite clay know as Bentogrout. Silo 2 contains 100,400 $\mathrm{ft}^{3}$ of K-65 waste and 11,100 $\mathrm{ft}^{3}$ of Bentogrout. The Bentogrout was added to both silos in 1991 to form a layer over the existing K-65 waste to reduce the potential for radioactive emissions to the environment. Details on the waste materials in the silos have been documented in a Fernald report. ${ }^{1}$

The purpose of the Accelerated Waste Retrieval (AWR) Project is to extract the material from Silos 1 and 2, transfer the material to interim storage tanks for staging before final remediation, reduce the radon concentration in the silo headspaces, provide radon control during retrieval and material storage, clean the silos and equipment for system closure, and handle secondary waste generated during the AWR Project. Design of the bulk waste retrieval system for the silos was prepared by Foster Wheeler in 1999-2000 and calls for hydraulic sluicing of the waste into four 750,000-gal interim storage tanks. Information on the Foster Wheeler design has been previously documented. ${ }^{2}$

DOE Fernald requested that the DOE Office of Science and Technology provide assistance in organizing a technical working meeting to discuss lessons learned from prior experiences at DOE sites with sluicing of material from large tanks. A technical working meeting, which included experts from industry, DOE facilities, and universities, was held on October 10 and 11, 2001. The experts felt that the most critical item of concern was the waste retrieval.

Recommendations were made on modifying the sluicing design in terms of the number and locations of sluice nozzles, the pump specified to retrieve the K-65 waste, and the pump location. The team of experts also recommended that a demonstration system be developed and operated with a physical surrogate material to demonstrate the efficacy of the proposed system in the sluicing of K-65 waste from the silos. Furthermore, the test system should provide critical information concerning system and component operation and maintenance as well as nozzle operation and optimization of the sluicing system characteristics. This report presents the results of the first series of tests conducted to meet these objectives. 


\section{DESIGNATION OF CORE TEAM AND KEY RESPONSIBILITIES}

This demonstration project was a collaboration of a broad team of experts, designers, and operators. Members of the team included Fluor-Fernald (project oversight and guidance); Jacobs Engineering Group (pump selection, component selection, and process engineering input); Oak Ridge National Laboratory (ORNL) (preparation of the test plan with input from the core team, data collection and analysis, and test oversight); TPG Applied Technology (TPG) (system design, system construction, system operation, and report preparation); and Pacific Northwest National Laboratory (PNNL) (surrogate specification).

\section{TEST FACILITY AND SYSTEMS}

Two test systems, each designed for a specific purpose, were installed to perform a series of tests. The first system, the Integrated Test Loop (ITL) was designed to demonstrate the operation of the waste retrieval process as a whole. The second system, the Component Test Loop (CTL), was designed to evaluate many of the key individual components of the waste retrieval system. Each system is described in detail in the following sections.

\subsection{THE INTEGRATED TEST LOOP}

The objective of the ITL, as stated above, was to demonstrate and evaluate the AWR sluicing operation at near full scale. The ITL utilized many of the actual operating modules and other components (i.e., pumps, valves, and instrumentation) that will be used in the sluicing operation at Fernald. A piping and instrument diagram for the ITL is presented in Fig. 3.1. The primary components of the ITL, as shown in Fig. 3.1, are the surrogate tank, a slurry pump (utilized to provide sluice water) and sluicer module, a slurry pump and slurry module, sluice water tanks, and slurry collection tanks. This system is designed for multiple short runs of about $1 \mathrm{~h}$ in duration.

During testing, water from the decant water supply tanks is pumped to the sluice nozzles. The sluice water then forms a slurry when it contacts the surrogate and mobilizes the surrogate to the slurry pump. The slurry is then pumped from the surrogate tank to the slurry receipt tank, where it is allowed to settle. Next, the supernatant is recovered and pumped to the decant water supply tanks, where it is used for the next test. The following sections provide details concerning some of the individual components in the ITL. 


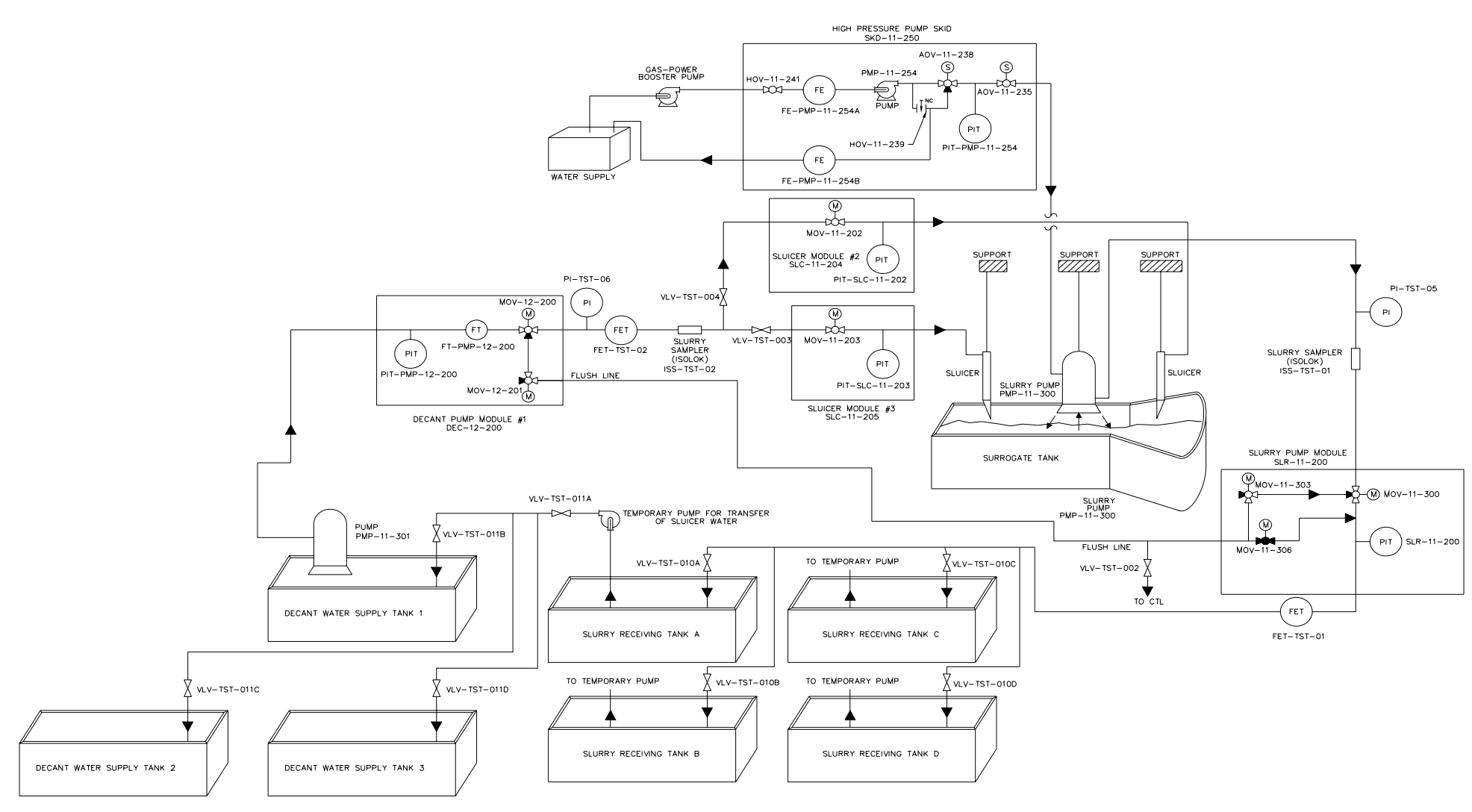

Fig. 3.1. Piping and instrument diagram for the ITL. 


\subsubsection{Surrogate Tank}

The surrogate tank (a photograph is shown in Fig. 3.2) was designed to represent the actual silo diameter. The tank is approximately $70 \mathrm{ft}$ long by $15 \mathrm{ft}$ wide by $8 \mathrm{ft}$ deep, with an arc section on one end to represent the silo wall. The tank has been equipped with two sluicer nozzles and a slurry pump, which are positioned to simulate the distances between the nozzles, the pump, and the silo wall in the actual bulk waste retrieval system planned for deployment in the silos. The nozzles and slurry pump are full scale and identical to those planned for deployment at Fernald. The surrogate material tank also has standpipes for determining the depth of any free liquid in the tank.

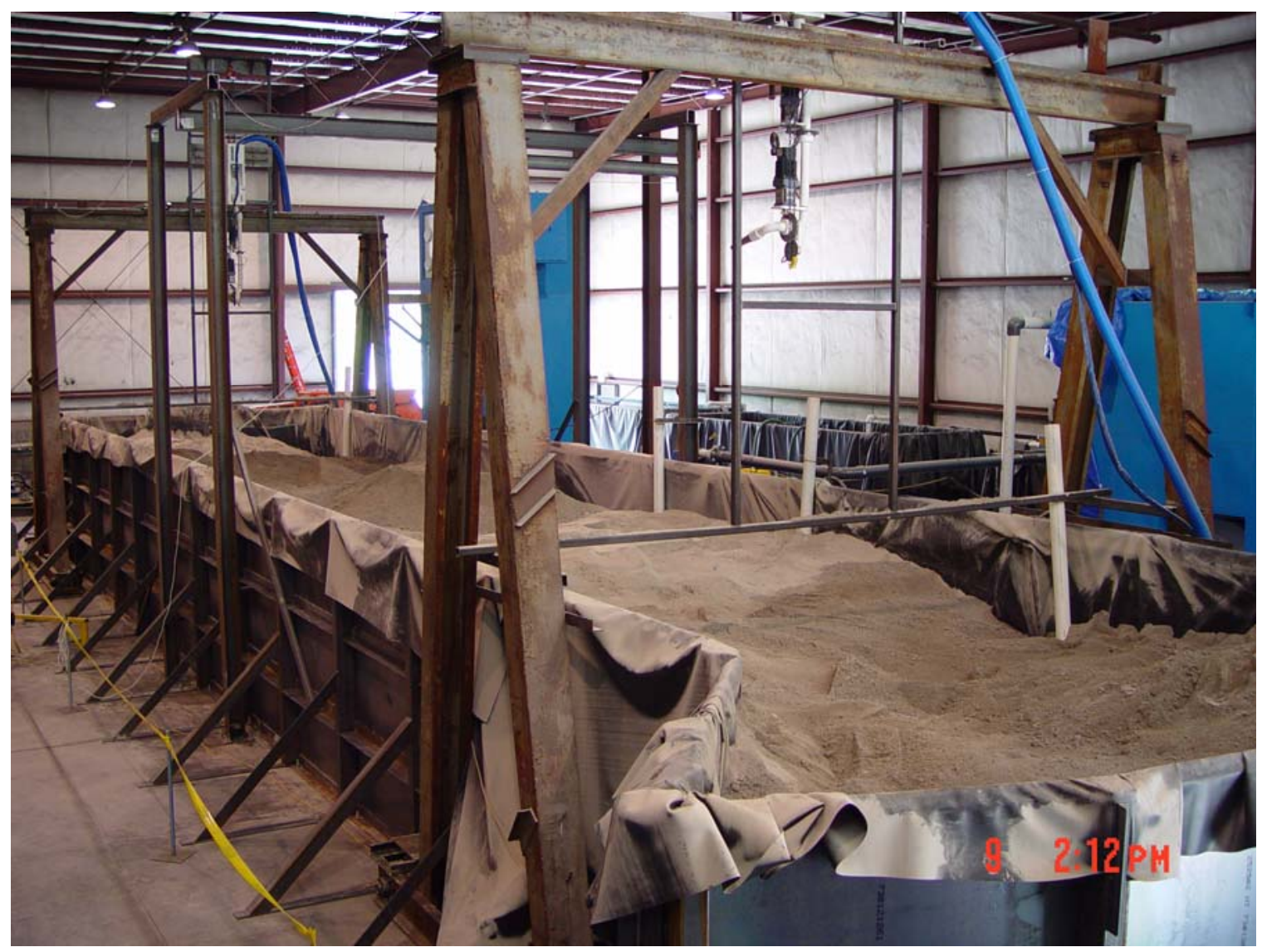

Fig. 3.2. View of the surrogate tank prior to testing.

\subsubsection{Slurry and Sluice Pumps}

One of the most important components tested in the ITL was the slurry pump. A pump selection process was undertaken prior to the testing and is documented in another report. ${ }^{3}$ The pump chosen for testing is by Hazelton Pumps, Inc. The specific model is a series 3-20 type SHW pump. Initial (as-tested) specifications for the selected Hazelton pumps are as follows: 
- The Hazelton SHW will pump $350 \mathrm{gal} / \mathrm{min}$.

- The total dynamic head for the pump is $208 \mathrm{ft}$ at $1350 \mathrm{rpm}$ and $450 \mathrm{ft}$ at $1975 \mathrm{rpm}$.

- The pump has an efficiency of $52 \%$.

- The pump has a 3-in. discharge flange (150\# ANSI), flat faced.

- The maximum size of spherical solids through the impeller is 1.25 in.

- A 20-in. minimum submergence over the suction inlet is required for full flow.

- The normal pump operating temperature is ambient.

- The impeller has a design diameter of 18 in.

A photograph of the pump is shown in Fig. 3.3.

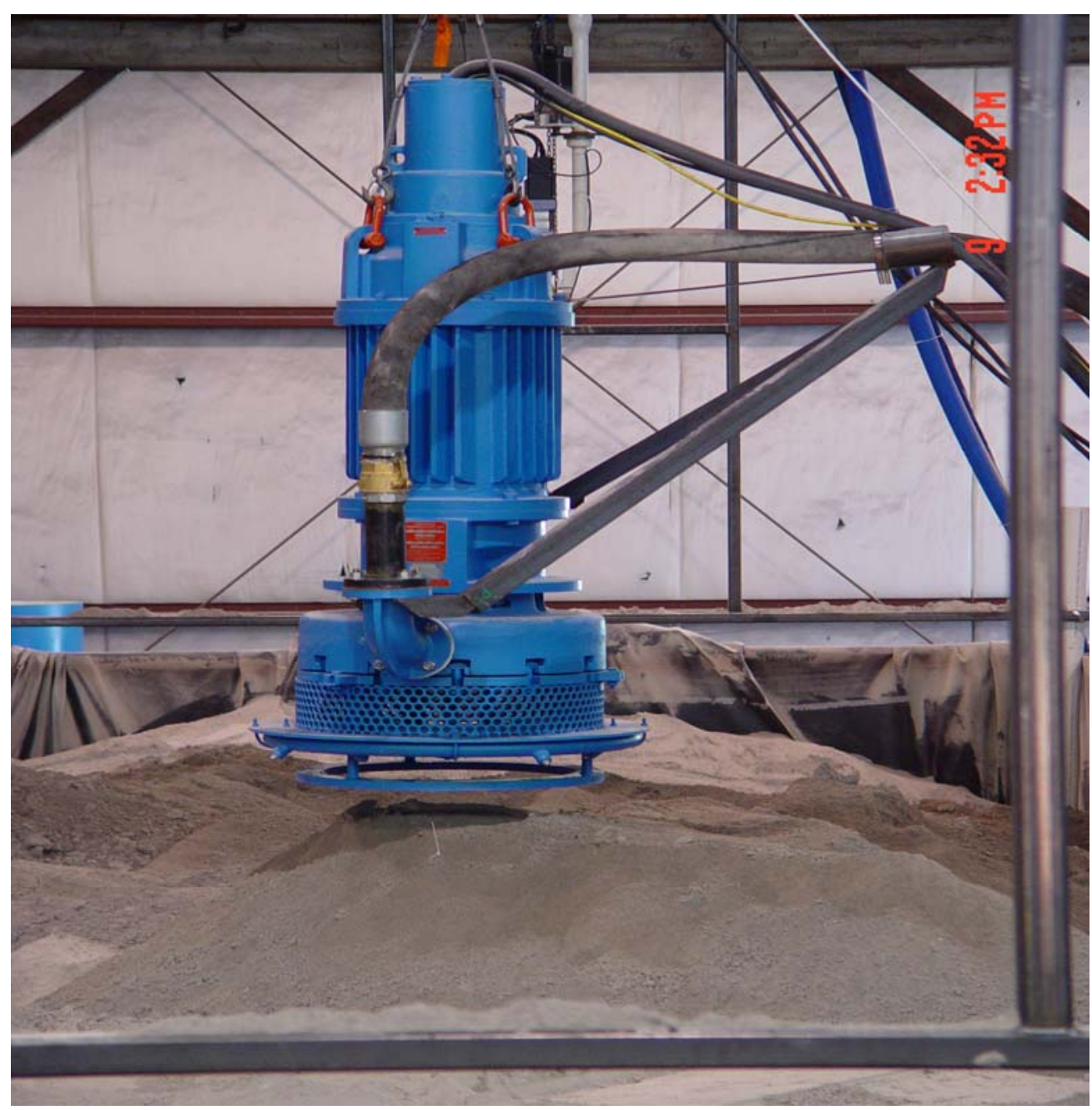

Fig. 3.3. The slurry pump.

The Hazelton SHW had several key features that made it the pump of choice. First, the pump was delivered with an oversized motor that allows it to be run indefinitely without external cooling. Secondly, the pump can develop enough head to allow it to serve as both a slurry pump 
and a sluice water pump. Three pumps were tested during the cold testing. One, delivered with a high-pressure spray ring, was used as the ITL slurry pump. The other two, the same pump model without the spray ring, were either used as a sluice water pump in the ITL or tested in the CTL. The slurry pump and the pump tested in the CTL were powered by a 50-hp variablefrequency drive (VFD), and the sluice water pump was powered by a 100-hp VFD.

\subsubsection{Other Components}

The ITL has several other components worth noting, including two Isolok sampling devices and two mass flow measurement devices (one of each device in the sluice water and slurry lines). The Isolok samplers are designed to sample a slurry stream in situ by inserting a "thief" into a flowing stream of slurry. The Isolok can be programmed to take a sample periodically, which allows automated composite sampling.

The other component of note is an instrument assembly designed to measure mass flow of the slurry. This mass flow assembly is a combination of two independent instruments. One is a magnetic flowmeter (a technology that is well demonstrated in slurry service), and the other is a Solartron liquid density transducer. The magnetic flowmeter measures the volumetric flow of the slurry. The densitometer, which operates on the vibrating element principle with the element being a tuning fork, is immersed in the liquid being measured and measures the density. Readings from these two elements are used to calculate the solids concentration in the slurry. This assembly was tested in both the slurry streams and the sluice water streams.

\subsection{THE COMPONENT TEST LOOP}

A piping and instrument diagram for the CTL is presented in Fig. 3.4. A photograph of the CTL is shown in Fig. 3.5. The CTL was operated around the clock for extended periods of time to gather data on individual components that are planned for use in the remediation of the Fernald silos.

A slurry surrogate, similar to the physical surrogate used in the ITL, was prepared and placed in the feed tank. The target concentration of solids in the surrogate was $15 \%$ by weight. The slurry pump, which is identical to the pumps used in the ITL, circulated the slurry at flows of approximately $350 \mathrm{gal} / \mathrm{min}$ through the test loop and back to the feed tank. The pressure, flow, solids concentration, and the temperature on the pump discharge were logged, and an Isolok sampler on the slurry pump effluent line was included for taking grab samples. The CTL contains a valve for adjusting the back-pressure on the slurry pump to verify pump curves, as well as clear sections of pipe to determine the critical velocity at which the solids in the surrogate begin to settle. The various components of particular interest that were evaluated during these extended runs included a DeZurik brand plug valve, an Everlasting brand diverter valve, an RF brand pinch valve, a full-port two-way ball valve, full-port three-way ball valves, a standard long radius elbow, a bend on a 40 -in. radius, a mass flowmeter, a magnetic flowmeter, a densitometer, and an Isolok sampler. 
$\infty$

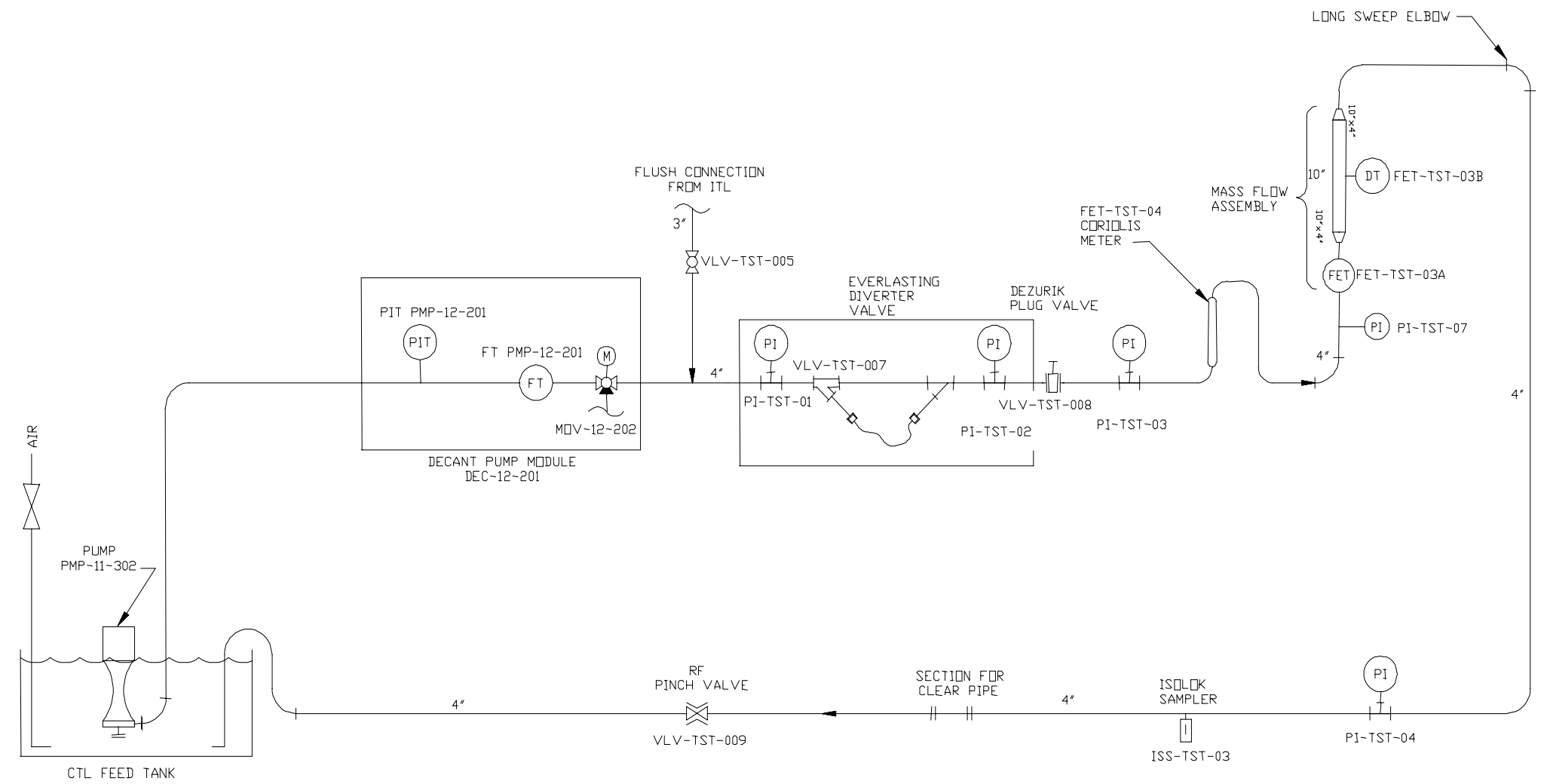

Fig. 3.4. Piping and instrument diagram for the CTL. 


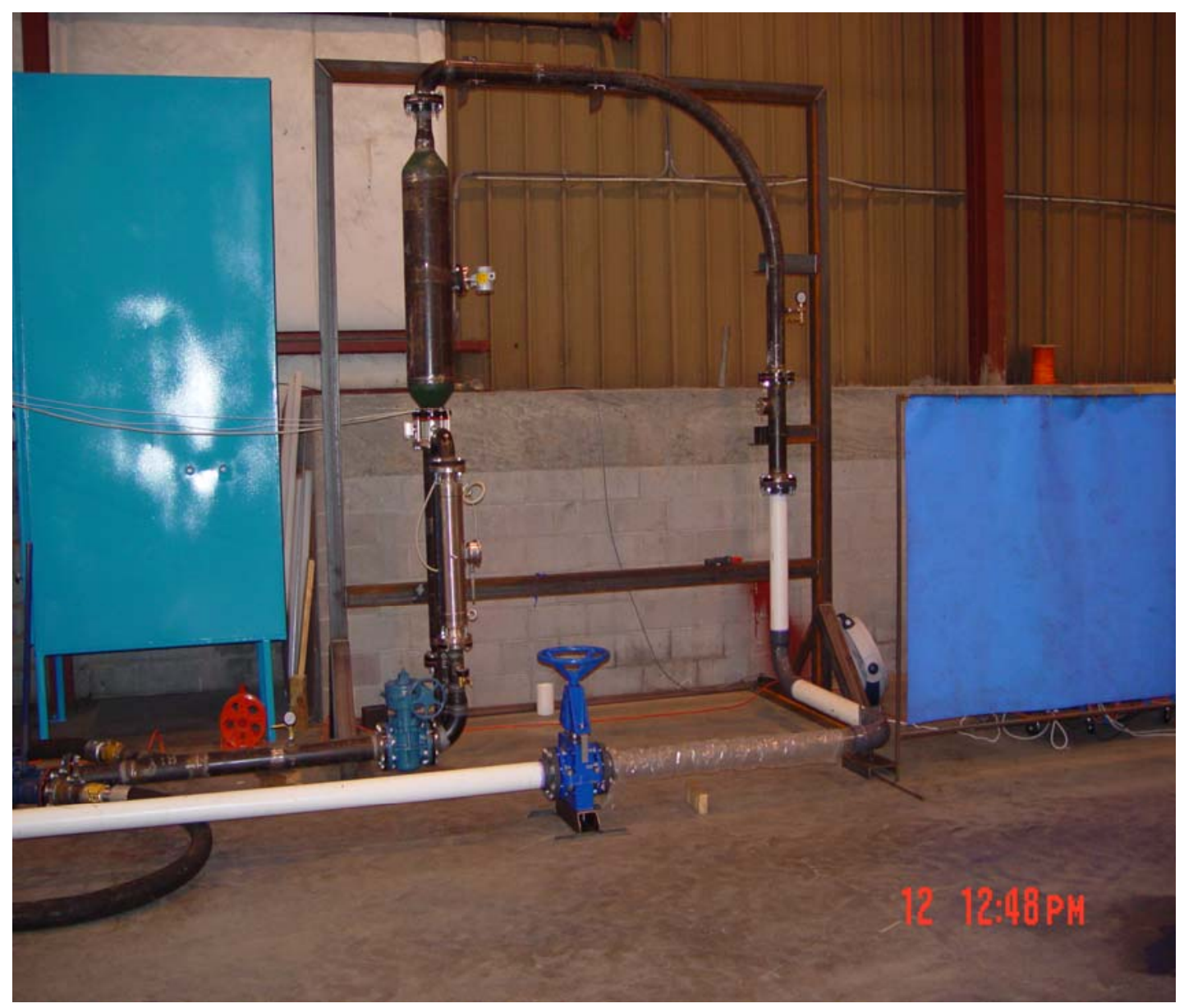

Fig. 3.5. The CTL.

\subsection{SURROGATE}

The K-65 waste consists primarily of solids of raffinates from processing operations on Belgian Congo ores for the recovery of uranium. The K-65 material contains a significant amount of lead (8.9\%), iron (4.1\%), and barium (4.4\%). Therefore, this material is slightly denser, with a higher specific gravity (average 2.97, standard deviation of 0.13 ) than that of typical sands or minerals (specific gravity of 2.65). Personnel from PNNL, who have an expertise in surrogate development and specification based on previous work with similar wastes, studied the characterization data from the silos and developed a specification for the K-65 surrogate. Information on the surrogate and its development has been summarized in a PNNL report. ${ }^{4}$

The specifications for a physical surrogate developed by PNNL staff were met by combining $23 \%$ of a crushed block material with $77 \%$ of a crushed limestone material from a local vendor. The PNNL report discusses the issues associated with the variation in the surrogate and the specification requirements. A comparison of the surrogate and the specification is provided in Table 3.1. 
Table 3.1. Comparison of surrogate and specification requirements ${ }^{a}$

\begin{tabular}{|c|c|c|c|c|}
\hline $\begin{array}{l}\text { Screen size } \\
\text { (mesh no.) }\end{array}$ & Block material & Limestone material $^{a}$ & $\begin{array}{l}\text { Combined } \\
\text { material }^{b}\end{array}$ & $\begin{array}{c}\text { Fernald } \\
\text { specifications }\end{array}$ \\
\hline 4 & 99 & 100.0 & 99.8 & 100.0 \\
\hline 8 & 73 & 99.9 & 93.7 & 97.3 \\
\hline 16 & 50 & 99.0 & 87.7 & 93 \\
\hline 30 & 35 & 98.0 & 83.5 & 87.5 \\
\hline 50 & 26 & 95.9 & 79.8 & 79.5 \\
\hline 100 & 19 & 87.2 & 71.5 & 66.5 \\
\hline 200 & 14 & 67.4 & 55.1 & 54.0 \\
\hline
\end{tabular}

${ }^{a}$ Values listed indicate the percent passing through the screen size indicated but not the next-finer one. Specific gravities are 2.82 for the combined surrogate and 2.97 for the Fernald specification.

${ }^{b}$ Contains $23 \%$ block material and 77\% limestone.

The block and limestone materials were mixed using a procedure developed by TPG. The mixing procedure is also referenced in a PNNL report. ${ }^{4}$

An adjustment to the above surrogate formula was made late in the program to support CTL operations. A vendor was located that offered graded silica sand, novaculite and $\mathrm{TiO}_{2}$. PNNL staff were able to more closely match the K-65 material by formulating a blend of the block material, crushed limestone, and the new materials.

One important aspect of the silo material that will influence its behavior is the bentonite cover that was placed on the material in 1991. The material, Bentogrout, was added to reduce the potential for radioactive emissions to the environment. Consequently, a Bentogrout cap was placed over the K-65 surrogate during a portion of the ITL testing to simulate the waste condition in Silos 1 and 2. Testing was also conducted in the CTL with different combinations of K-65/Bentogrout to bound the range of compositions expected to be encountered during the actual remediation of the silos. In addition, debris (e.g., plastic bags) was added to the surrogate tank to determine how the slurry pump would handle this material.

\section{INTEGRATED TEST LOOP RESULTS}

A total of 13 documented runs have been completed in the ITL. The test plan initially called for eight runs; however, another five runs were included to more completely explore sluicing operations. General results and conclusions of initial ITL testing are summarized in the following sections. Run-specific data of results and summaries are included in the appendix. 


\subsection{SLUICING PERFORMANCE}

\subsubsection{Nozzle and Configuration}

Two nozzle configurations were tested in the ITL. One configuration was two nozzles (15/16-in. orifice and/or 7/8-in. orifice) operating alternately at a sluice water flow of approximately $280 \mathrm{gal} / \mathrm{min}$, and the other consisted of two smaller nozzles (5/8-in. orifice) operating concurrently at approximately $140 \mathrm{gal} / \mathrm{min}$ each. In each configuration, the sluice water pressure in the sluice module was approximately 150 psig.

The test results indicate that the preferred configuration is the use of the higher-flow nozzles operating alternately. Although the solids concentration in the slurry was approximately equal for each nozzle size (see Fig. 4.1), this conclusion was based primarily on observations of the depth profile in the surrogate bed after several ITL runs.

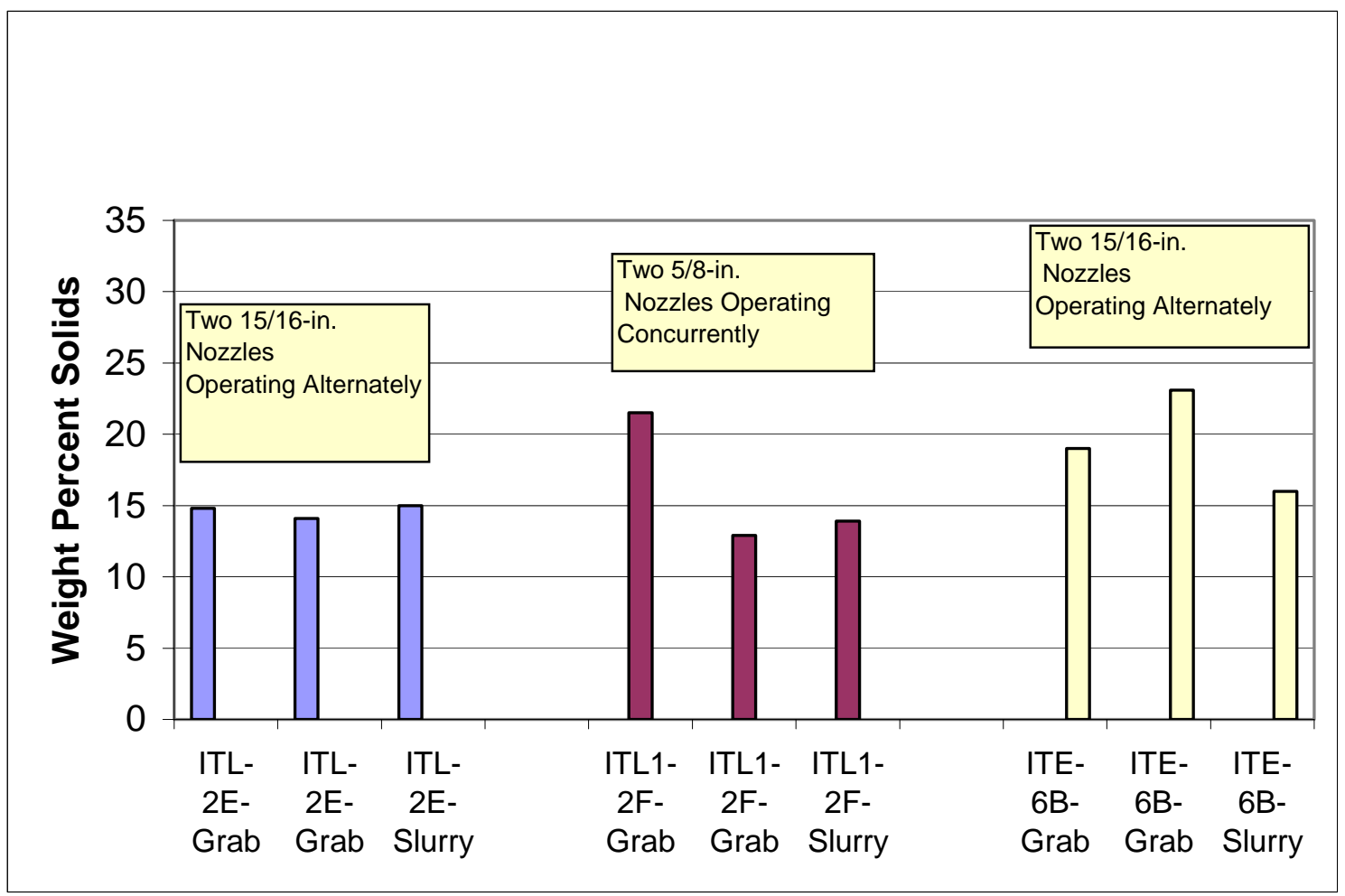

Fig. 4.1. Comparison of the performance of different nozzle configurations.

Upon completing the Series 1 tests, preliminary indications were that concurrent operation of two nozzles was preferred. However, after several more runs, it was observed that the surrogate bed developed a depth profile in which the area of the bed directly under and in close proximity to the pump was elevated with respect to the rest of the bed when the lower-flow nozzles were used simultaneously. Moreover, the profile could not be altered by adjusting the volumes of sluice water available when the lower-volume nozzles were used. When the higher-flow nozzles were installed and run alternately, sufficient sluice water flow was present to consistently move the material directly under the pump and develop a bed profile that was evenly depressed under the pump. 


\subsubsection{Spray Ring Configuration and Operation}

The high-pressure spray ring, as delivered from Hazelton, was ineffective. The nozzles that were initially installed provided only a small direct water stream and did not impact the surrogate significantly. The initial nozzles were replaced with a set of adjustable nozzles, which showed significant wear after only two tests (approximately $1 \mathrm{~h}$ of operating time). Finally, the ring was modified and Viper Turbo nozzles were tested in the system. These nozzles appeared to effectively impact the surrogate bed (see Fig. 4.2) and performed reliably during testing.

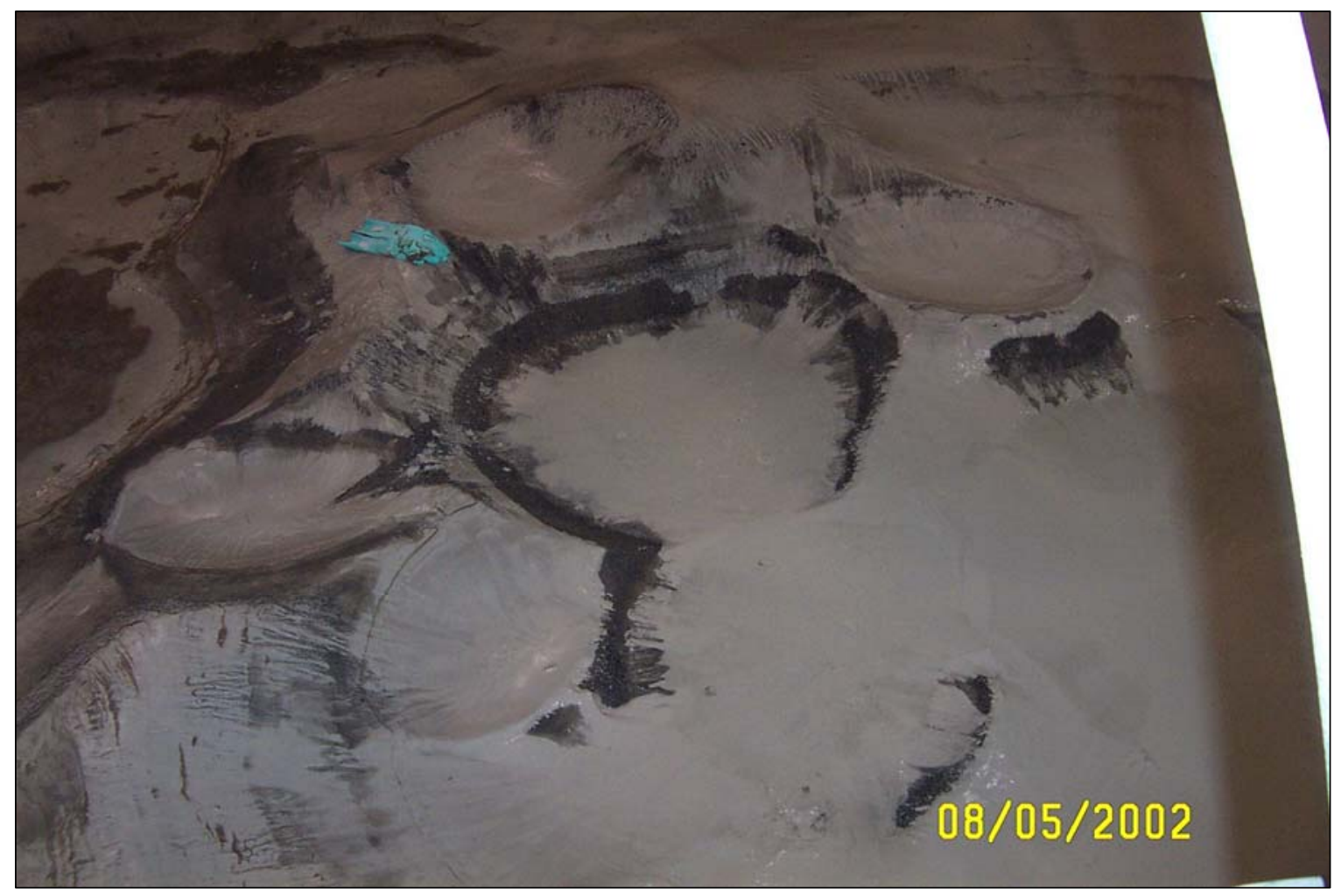

Fig. 4.2. Nozzle pattern for the Viper Turbo nozzles.

The testing of the spray ring resulted in two important observations. First, water flow must be maintained to the nozzles whenever they are submerged in the surrogate. In every case, if water flow to the nozzles was interrupted during a run, the nozzles plugged and had to be either cleaned or replaced.

The other major observation concerned operation with the Bentogrout cap covering the surrogate. When the testing was initiated with the cap in place, the spray ring was operated for several minutes prior to turning on the sluicers. The high-pressure spray readily cut through the cap, removing a small amount of the Bentogrout under the nozzles. When the sluicing was started, however, the sluice water stream readily removed the Bentogrout cap almost immediately upon contact. Consequently, the large flow of water available from the sluicing nozzles is far more effective in mobilizing the Bentogrout cap than is the operation of the spray ring. 


\subsubsection{Pump Performance and Operation}

The Hazelton pumps performed quite well during the testing. The pumps were taken through a variety of run conditions and speeds in the various runs. The following summarizes the significant results and observations concerning the pump and associated process equipment.

- The sluicing operation is quite dynamic. Consequently, the slurry pump operates over a wide range of speed, flow, and pressure. In many of the ITL tests, the slurry pump was operated both dry (i.e., the pump was running but there was no flow of slurry established) and while pumping slurry. In many instances, the pump would be started, several minutes would elapse before the slurry depth was sufficient for slurry flow to be established, pump flow would be established for a period of time, and the pump would then lose suction and run dry until the flow was reestablished. The pump appeared to handle this type of operation well without cavitating or pulsing.

- The sluice pump operated consistently throughout the testing; however, the 100-hp VFD was insufficient to allow the pump to run at $1975 \mathrm{rpm}$ and $280 \mathrm{gal} / \mathrm{min}$. Operation at these levels requires a 125-hp VFD.

- During the Bentogrout runs, the pump screen was blinded with surrogate. Figure 4.3 is a photograph of the pump screen after a Bentogrout run. Initially, the pumping rate was similar to that of the surrogate runs without Bentogrout. At times, however, the slurry flow would be dramatically reduced. The screen could be readily cleaned by raising the pump above the surrogate bed and cleaning it with one of the sluice nozzles.

- Debris was added to the system as part of Run 6. The debris included angle iron, a cinder block, plastic gloves, several sample bottles, a two-by-four, and a plastic bag of debris. The results of the runs were uneventful. The debris could be easily manipulated with the spray nozzles and kept away from the slurry pump. The Hazelton representative did have a concern with the external agitator potentially becoming entangled with a glove or piece of wire and recommended operating without the agitator.

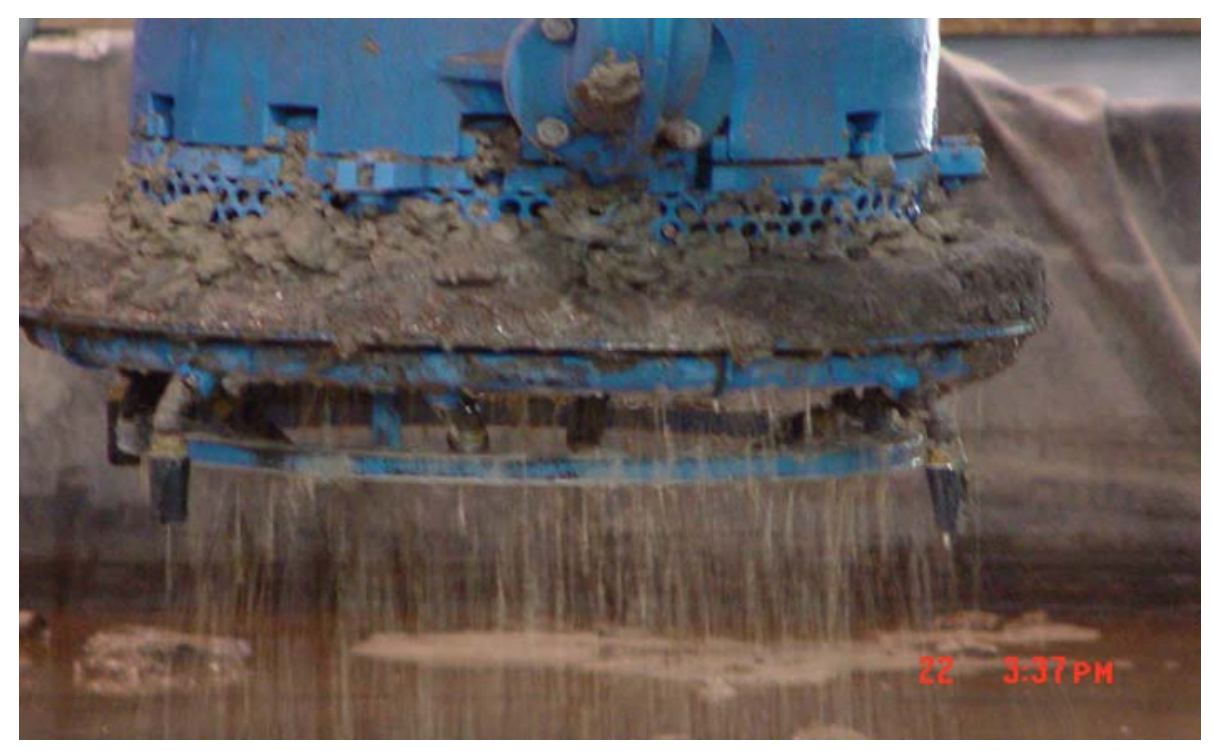

Fig. 4.3. Pump screen after an ITL run with Bentogrout added to the surrogate. 


\subsection{PERFORMANCE OF SOLATRON UNIT}

One of the key equipment assemblies tested in the ITL was the combination of a Solartron model 7826 insertion density transducer and a magnetic flowmeter. As previously indicated, this assembly was designed to allow the measurement of solids concentration in the slurry. The density transducer is used to measure the density of the flowing slurry. When combined with a volumetric flow measurement taken by the magnetic flowmeter, a mass flow (i.e., pounds per hour) is calculated. Furthermore, the equations provided with the Solartron flow computer can also be used to correlate the slurry density to the solids concentration (percent solids by weight) and an estimate of solids flow can then be calculated.

This system has not performed acceptably in either the ITL or CTL. The installation, calibration, and programming directions provided in the Solartron manual were followed to install and program the Solartron units. Initially, the flow computers were programmed using a water density of $8.34 \mathrm{lb} / \mathrm{gal}$. However, after initial measurements were taken in each of the three densitometers, the following water density readings were recorded for the three Solartron units:

Sluice water loop in the ITL $-8.17 \mathrm{lb} / \mathrm{gal}$ (an error of $2 \%$ )

Slurry loop in the ITL $-8.2 \mathrm{lb} /$ gal (an error of $1.7 \%$ ), current reading: $7.7 \mathrm{lb} / \mathrm{gal}$ (an error of $8 \%$ )

CTL loop - $8.0 \mathrm{lb} / \mathrm{gal}$, drifting to $7.8 \mathrm{lb} / \mathrm{gal}$ (an error of 2.4 to $6.5 \%$ )

While these errors appear to be relatively small, the difference in the density of water and that of a slurry of $10 \%$ solids concentration is approximately $5 \%$ - a value that is well within the measurement error.

Several other problems occurred with the use of the Solartron units.

- Calculation of the mass or volume concentration in the slurry requires that the average particle density of the solids be known. In other words, to predict solids concentration, the composition of solids must remain fixed. If the composition of the solids changes, the particle density also changes (e.g., solids-rich Bentogrout vs solids containing little or no Bentogrout) and significant error is introduced in the calculation of the solids concentration.

- The Solartron unit operates using a tuning fork arrangement. During the first ITL run, the Solartron unit failed to give any readings. When the unit was removed from the ITL, a piece of gravel was observed to be lodged in the tuning fork, causing the unit to fail. Solids similar to the gravel are expected in the K-65 material; consequently, this type of failure is probable in full-scale operation.

- The Solartron did not perform consistently in our testing. Constant recalibration will be required to reduce error. 
Based on their performance in testing, it was concluded that the Solartron units are not suitable for inclusion in the AWR design or operation. However, the magnetic flowmeters appear to give very accurate and reproducible measurements. Practically, the operator will be able to use a combination of pump performance (e.g., torque, rpm, amperage requirements) and volumetric flow measurements from the magnetic flowmeters to run and control sluicing operations.

\subsection{SOLIDS CONCENTRATION IN THE EFFLUENT}

Slurry solids concentration is a very important parameter for both the design and operation of the AWR system. In earlier designs, significant attention was paid to carefully controlling the solids concentration to minimize the wear on components as well as eliminate the potential for plugging the equipment.

The concentration of solids in the ITL slurry effluent varied considerably throughout the testing. There were several contributing factors such as the state of the surrogate (e.g., early in the testing it had not been saturated and packed), the specific test being run, and the skill of the operator. However, the concentrations did appear to become more consistent in the later runs.

Table 4.1 summarizes the solids concentrations of the ITL slurry effluent for several ITL runs conducted prior to the addition of Bentogrout. Two types of samples were taken: grab and composite samples. The grab samples were taken directly from the discharge piping at the discharge tank, and the composite samples were taken by the Isolok sampler throughout the run. Also, in these runs, the Isolok sampler was operated only while the slurry flow was established. Earlier testing had indicated that if the Isolok sampler was operated during periods of no slurry flow, a stagnant stream would be sampled, potentially biasing the data.

The average solids concentration of all of the samples shown in Table 4.1 is $16.3 \%$. The average concentration for the grab samples is $16.4 \%$, and that for the composite samples is $15.9 \%$. Quite a range of values (5.6 to 30.3\%) was observed, primarily in the grab samples, resulting from the dynamic nature of the operation. Three sources of variability are possible: the operator is constantly moving the sluice nozzle and fanning the surrogate tank, which moves material to the pump at differing rates; the pump may be on the surrogate surface or above the surface, depending on the time of the sample; or the flow from the pump may be either steady, just starting, or even decreasing, depending on the pool depth around the pump.

After Bentogrout was added to the system, the solids concentration increased dramatically. The solids concentrations are shown in Table 4.2. The average solids concentration in Run ITL-4 was $33.8 \%$, with the grab samples averaging $36.4 \%$. The only composite sample had a solids concentration of $26 \%$. The reason for this increase in solids concentration is likely twofold: (1) the Bentogrout itself as a solids contributor and (2) suspended (colloidal) Bentogrout acting to increase the density and viscosity of the sluice water and enhance the mobilization of solids. More tests need to be run in order to confirm the solids concentration with Bentogrout in the system. 
Table 4.1. Summary of solids concentrations in several of the ITL runs prior to Bentogrout addition

\begin{tabular}{|l|c|c|c|}
\hline Sample identification & Description of sample & $\begin{array}{c}\text { Specific } \\
\text { gravity }\end{array}$ & $\begin{array}{c}\text { Solids } \\
\text { concentration } \\
\text { (percent by } \\
\text { weight) }\end{array}$ \\
\hline ITL-2C-Grab & Slurry receipt line (grab) & 1.03 & 5.6 \\
\hline ITL-2C-Grab & Slurry receipt line (grab) & 1.65 & 30.3 \\
\hline ITL-2C-Slurry & ISS-TST-002 (composite) & 1.09 & 17.5 \\
\hline ITL-6-Grab & Slurry receipt line (grab) & 1.13 & 13.8 \\
\hline ITL-6-Grab & Slurry receipt line (grab) & 1.06 & 11 \\
\hline ITL-6-Slurry & ISS-TST-002 (composite) & 1.04 & 16.3 \\
\hline ITL-2E-Grab & Slurry receipt line (grab) & 1.11 & 14.8 \\
\hline ITL-2E-Grab & Slurry receipt line (grab) & 1.09 & 14.1 \\
\hline ITL-2E-Slurry & Slurry receipt line (grab) & 1.00 & 15 \\
\hline ITE-6B-Grab & Slurry receipt line (grab) & 1.14 & 19 \\
\hline ITE-6B-Grab & Slurry receipt line (grab) & 1.17 & 23.1 \\
\hline ITE-6B-Slurry & Slurry receipt line (grab) & 1.09 & 16 \\
\hline ITL1-2F-Slurry & ISS-TST-002 (composite) & 1.05 & 13.9 \\
\hline ITL1-2F-Grab1 & Slurry receipt line (grab) & 1.15 & 21.5 \\
\hline ITL1-2F-Grab2 & Slurry receipt line (grab) & 1.07 & 12.9 \\
\hline
\end{tabular}

Table 4.2. Summary of solids concentrations in Run ITL-4 with Bentogrout

\begin{tabular}{|c|c|c|c|}
\hline Sample identification & Description of sample & $\begin{array}{c}\text { Specific } \\
\text { gravity }\end{array}$ & $\begin{array}{c}\text { Solids concentration } \\
\text { (percent by weight) }\end{array}$ \\
\hline ITL4-Slurry & Slurry receipt line (composite) & 1.16 & 26.0 \\
\hline ITL4-Grab & Slurry receipt line (grab) & 1.32 & 39.8 \\
\hline ITL4-Grab & Slurry receipt line (grab) & 1.29 & 37.1 \\
\hline ITL4-Grab & Slurry receipt line (grab) & 1.23 & 32.3 \\
\hline
\end{tabular}

\subsection{PARTICLE SIZE DISTRIBUTION}

An appendix to this report, including the CTL data, provides a thorough review of this topic. 


\section{DESIGN RECOMMENDATIONS}

The previous sections of this report have detailed the results and conclusions from the ITL testing. The objective of this section is to summarize recommended design changes resulting from the initial ITL testing.

- The Hazelton series 3-20 type SHW pump is an appropriate choice for both the slurry and sluice pumps. The pumps tested in the cold test program performed consistently, and no problems were observed with their operation. The VFDs used in cold testing were undersized and did not allow complete utilization of the pump.

- Upon observing the cold test operation, a Hazelton representative recommended that the pump be modified by removing the external agitator (removal of the agitator is not expected to degrade the performance of the pump); replacing the 125-hp motor with a 200-hp motor to allow higher delivery pressures for sluicing; and replacing the 18-in. impeller with a 19.5-in. impeller, also to allow higher delivery pressures.

- The VFD supplying the pumps should be $150 \mathrm{hp}$.

- The Solartron densitometer did not perform well in our testing and should not be used in full-scale operation.

- Cold testing used visual means to determine when the pump was on the surrogate surface. However, observation of the pump in the silos may become obscured during operation. A load cell should be installed on the pump hoist to give a remote indication of when the pump is on the surrogate.

- The dilution line in the slurry module, designed to allow the control of solids concentration in the slurry, is unnecessary and should be removed. Cold testing has clearly shown that the pump and piping can readily handle solids concentrations as high as $40 \%$ by weight. Thus, solids control is unnecessary.

- The sluicers should employ 15/16-in. nozzles in alternate operation.

- The Viper Turbo nozzles are the nozzles of choice for the spray ring.

\section{RECOMMENDATIONS FOR FUTURE WORK}

Several questions remain unanswered from the initial testing. The following items summarize recommendations for follow-up work.

- The pump screen should be redesigned and tested because of problems with blinding during runs with Bentogrout. The screen should then be tested in a Bentogrout-rich surrogate.

- Because the representative from Hazelton Pumps, Inc., expressed concerns regarding entanglement of the agitator at the base of the pump with debris, additional testing without the agitator is recommended. Removal of the agitator will allow the pump inlet screen to be redesigned to minimize the possibility of debris getting into the pump.

- Approximately six to eight replicate runs should be conducted to quantify the concentration of solids in the slurry and thus allow an accurate prediction of a material balance in silo operations. 
- Three to five replicate runs are needed to determine the minimum flow necessary to prevent the spray ring nozzles from plugging. A continuous flow of water to the spray rings will contribute negatively to the AWR water balance. Minimization of the flow to the spray rings is necessary.

- $\quad$ The Coriolis meter should be installed and tested in the ITL sluice water stream during all of the above-mentioned runs.

- A longer run of steel pipe (200 to $400 \mathrm{ft}$ ) should be installed in the slurry pump outlet with a pinch valve or orifice plate to provide flow resistance and allow the slurry pump to be tested near expected full-scale discharge pressure requirements.

- $\quad$ Because of the problems in mobilization of the larger-particle-size materials, the CTL should be operated for approximately 2 weeks in continuous operation with the pump agitator removed. This will allow the CTL to be used to determine the ability of the valves, instruments, and fittings to withstand the abrasion and wear from the higher concentration of solids and from the larger particles. Removal of the agitator is also expected to enhance the mobilization of larger particles in the ITL.

\section{REFERENCES}

1. Final Operable Unit 4 Remedial Investiation Report, Fernald Environment Management Project, Fernald, Ohio, Nov. 3, 1993.

2. System Design Descriptions for the Silos 1 \& 2 Accelerated Waste Retrieval Project, Document Number 624-P622-30, Rev. 1, Foster Wheeler Environmental Corporation, Contract No. FSC-624, submitted to Fluor Fernald, Inc., Nov. 16, 2000.

3. Selection of a Slurry Pump for the Accelerated Waste Retrieval Project, Document Number 40710-RP-0013, Jacobs Engineering Group, April 23, 2002.

4. Surrogate Development for Fernald Silos 1 \& 2 Accelerated Waste Retrieval Project, PNNL13996, Pacific Northwest National Laboratory, Sept. 4, 2002. 
Appendix

\section{RUN SUMMARIES}





\section{A.1 ITL SERIES 1 RUNS}

\section{A.1.1 Objectives}

The primary objectives of the ITL Series 1 runs were to (1) determine the nozzle configuration that is most effective in mining the K-65 surrogate material, (2) determine the effective radius of the nozzles being tested with K-65 surrogate, and (3) determine the effectiveness of the nozzles in forming a sump around the slurry pump with the K-65 surrogate.

\section{A.1.2 Summary of Results}

- The initial conclusions from this set of runs indicated that two nozzles operating simultaneously at approximately $150 \mathrm{gal} / \mathrm{min}$ each were more effective than two nozzles operating alternately at approximately $280 \mathrm{gal} / \mathrm{min}$. The initial observations during the runs seemed to indicate that more material was being moved to the slurry pump when two nozzles were run simultaneously. However, a "sump" was not observed under the pump in either configuration. The next series of runs, Runs ITL-2-A and ITL-2-B, were conducted with the two 150-gal/min nozzles operated simultaneously.

- Approximately 30 min elapsed between the start of the sluice water flow and the start of slurry pumping. An adequate amount of water had to be added to the surrogate to allow the pump to prime itself.

- Directing the sluice spray directly to the intake of the pump would interrupt slurry flow.

- Both nozzles were able to direct the sluice water to the far end of the ITL storage tank. In addition, the nozzle nearest the curved end of the surrogate tank was able to effectively mine the surrogate in the curved portion of the tank directly behind the nozzle.

Photographs of the apparatus are included as Figs. A.1-A.5. Process and analytical data are provided in Tables A.1 and A.2, respectively. 


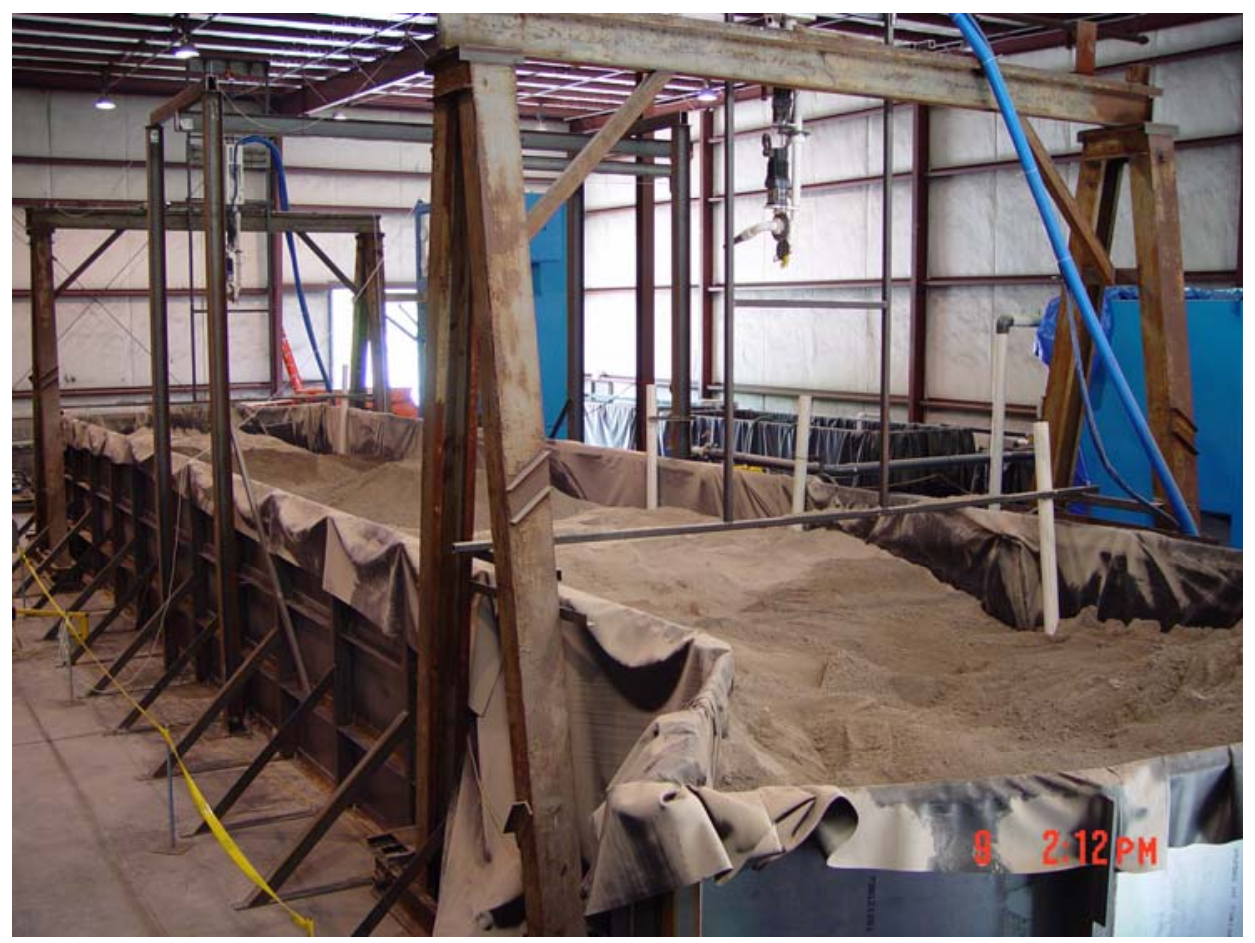

Fig. A.1. Surrogate tank prior to the start of the ITL-1 series runs.

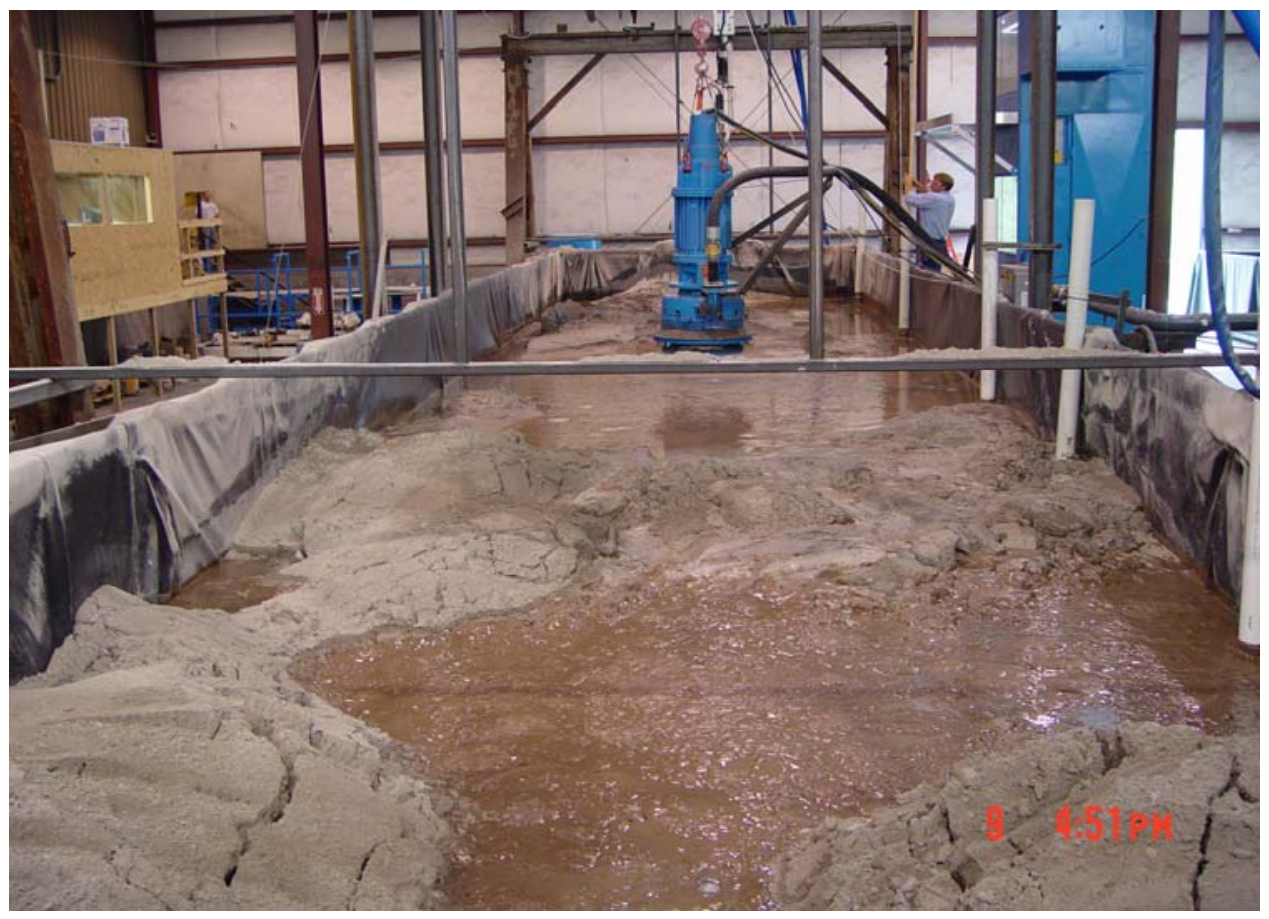

Fig. A.2. Surrogate tank after Run ITL-1-A. 


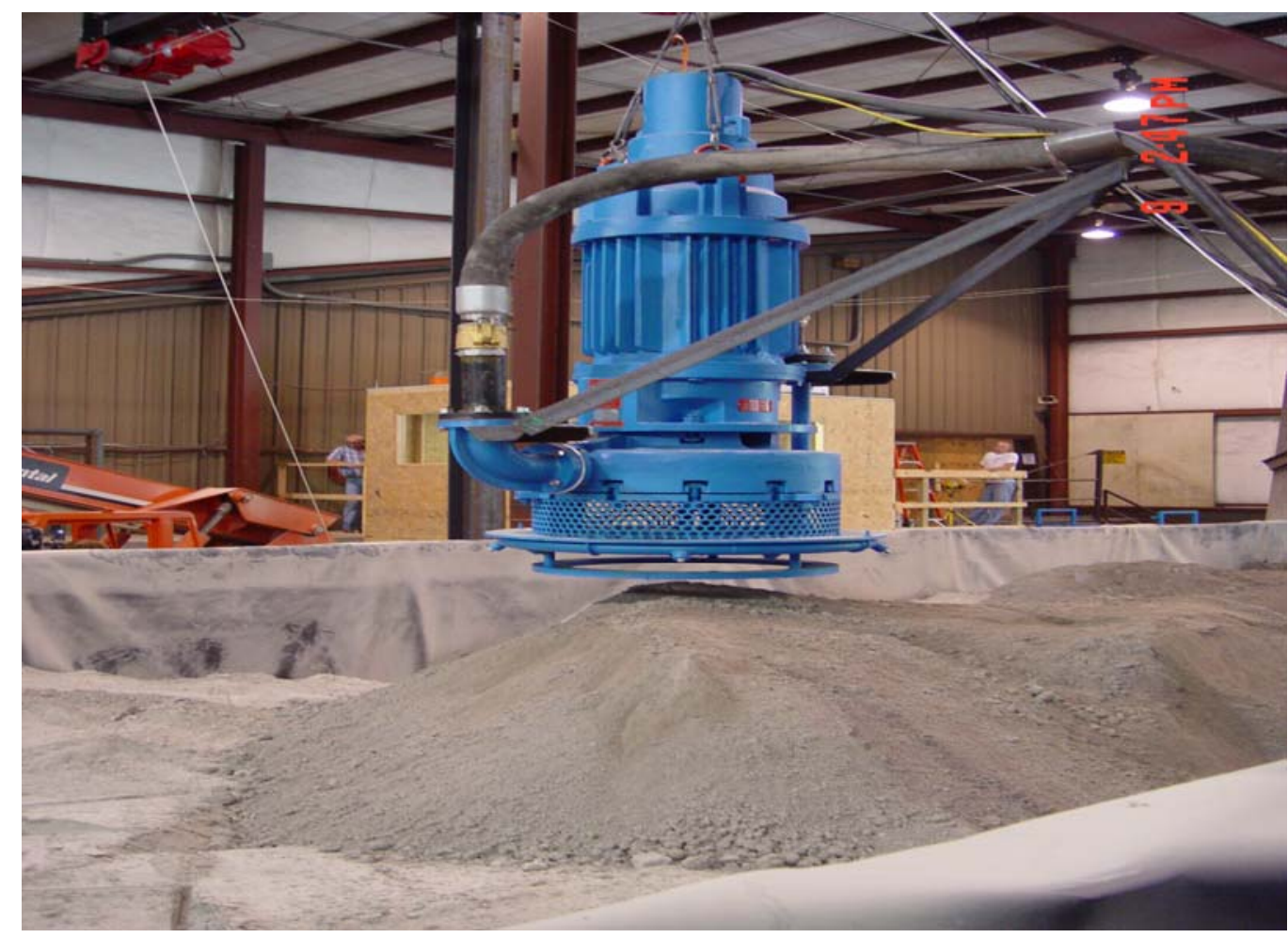

Fig. A.3. Area just under slurry pump before Run ITL-1-A.

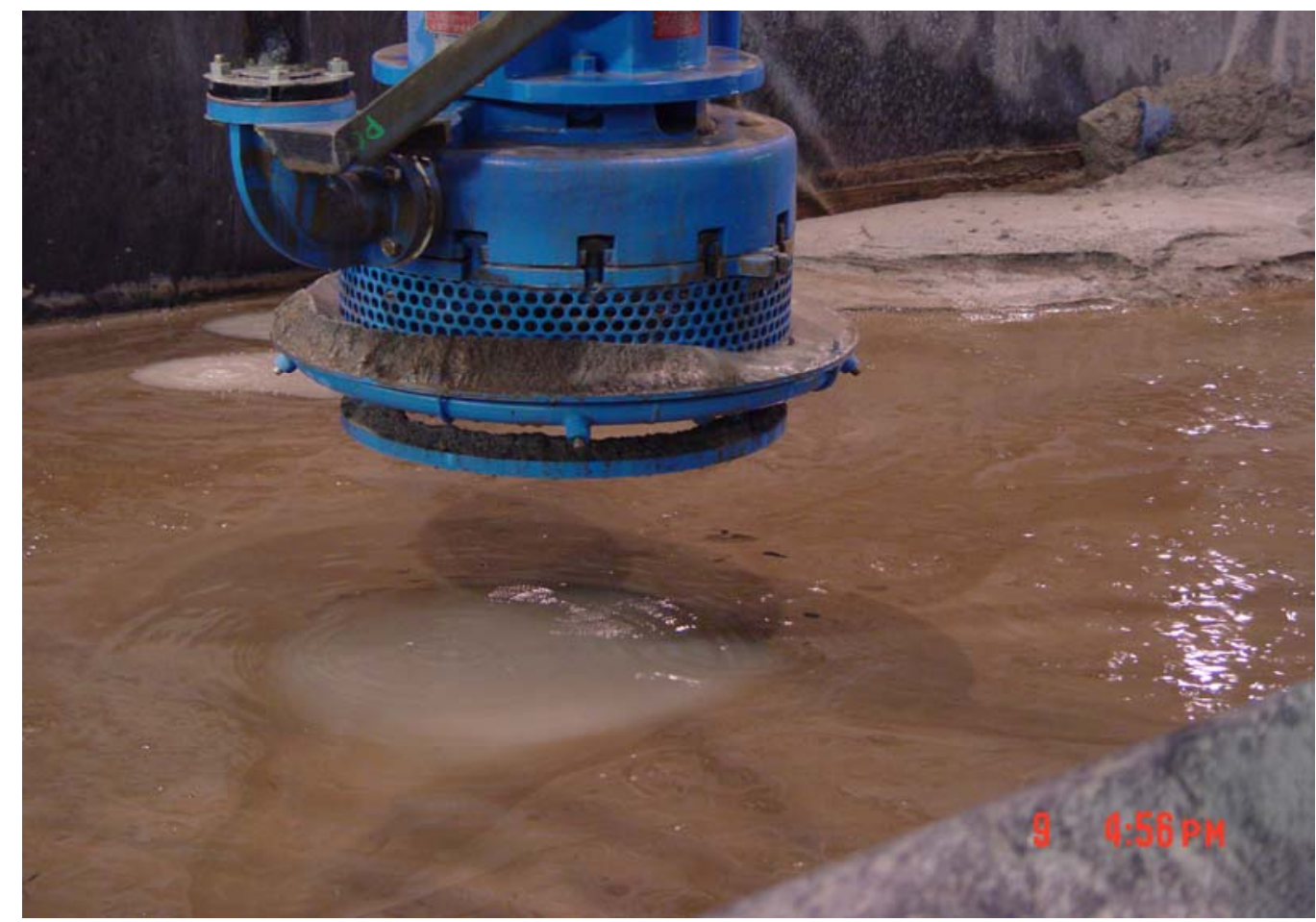

Fig. A.4. Area immediately under the slurry pump after Run ITL-1-A. 


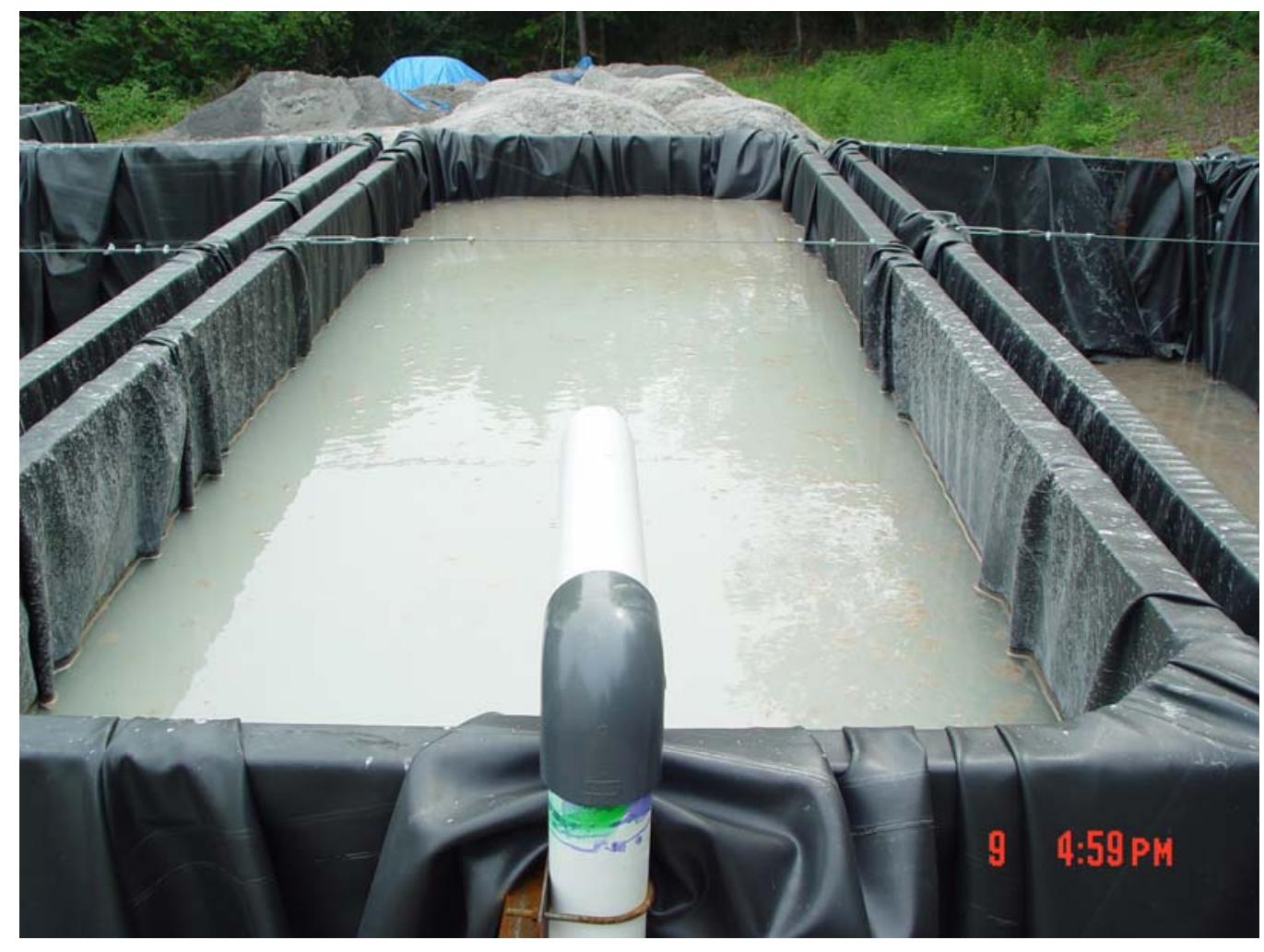

Fig. A.5. One of the receiving tanks after Run ITL-1A. 
Table A.1. Process data from the ITL Series 1 runs

\begin{tabular}{|c|c|c|c|c|c|c|c|c|c|c|c|c|c|c|c|c|c|c|}
\hline \multirow[b]{2}{*}{ Date/Time } & \multicolumn{9}{|c|}{ Inlet Line To Nozzles } & \multicolumn{6}{|c|}{ Slurry Pump } & \multicolumn{3}{|c|}{ Spray Ring } \\
\hline & $\begin{array}{c}\text { PIT-PMP- } \\
12-200\end{array}$ & $\begin{array}{c}\text { FT-PMP- } \\
12-200\end{array}$ & $\begin{array}{c}\text { FET-TST- } \\
02 A / B\end{array}$ & $\begin{array}{l}\text { FET-TST- } \\
\text { 02-Cumm }\end{array}$ & $\begin{array}{c}\text { PIT-SLC- } \\
11-202\end{array}$ & $\begin{array}{c}\text { PIT-SLC- } \\
11-203\end{array}$ & $\begin{array}{l}\text { Load- } \\
\text { PMP-301 }\end{array}$ & $\% \mathrm{~T}$ & $\begin{array}{c}\text { RPM-PMP- } \\
\quad 301\end{array}$ & $\begin{array}{l}\text { Load- } \\
\text { PMP-300 }\end{array}$ & $\begin{array}{l}\text { RPM-PMF } \\
300\end{array}$ & $\begin{array}{r}\text { - PIT-SLR } \\
11-200\end{array}$ & $\begin{array}{c}\text { 2- FET-TST- } \\
01 \mathrm{~A}\end{array}$ & $\begin{array}{c}\text { FET-TST- } \\
01 \mathrm{~B}\end{array}$ & $\begin{array}{l}\text { [- FET-TST- } \\
\text { 1B-Cumm }\end{array}$ & $\begin{array}{l}\text { Spray } \\
\text { Ring }\end{array}$ & Cumm & $\begin{array}{l}\text { Pelo- } \\
\text { Spray } \\
\text { Ring }\end{array}$ \\
\hline & (psig) & (gpm) & $(\mathrm{lb} / \mathrm{min})$ & (bs) & (psig) & (psig) & (amps) & $(\% \mathrm{~T})$ & (rpm) & (amps) & $(\mathrm{rpm})$ & (psig) & (gpm) & $(\mathrm{b} / \mathrm{min})$ & (bs) & $(\mathrm{gpm})$ & (gal) & (psig) \\
\hline $\begin{array}{ll}07 / 09 / 02 & 15: 57\end{array}$ & 40 & 136 & 0 & 0 & 36 & 0 & 49 & 50 & 939 & & 0 & 0 & & 0 & 0 & 0 & & \\
\hline 07/09/02 $\quad 15: 59$ & 58 & 163 & 0 & 0 & 50 & 0 & 56 & 67 & 1107 & & 0 & 0 & & 0 & 0 & 0 & & \\
\hline 07/09/02 $16: 09$ & 5 & 2 & 0 & 0 & & 0 & 0 & 0 & 0 & & 0 & 0 & & 0 & 0 & 0 & & \\
\hline 07/09/02 $16: 14$ & 100 & 219 & 0 & 0 & 89 & 0 & 79 & 114 & 1461 & & 0 & 0 & & 0 & 0 & 0 & & \\
\hline 07/09/02 $16: 19$ & 122 & 241 & 0 & 0 & 104 & 0 & 91 & 135 & 1591 & & 718 & 1 & & 0 & 0 & 0 & & \\
\hline 07/09/02 $16: 24$ & 117 & 240 & 1 & 2 & 106 & 0 & 91 & 137 & 1591 & & 0 & 1 & & 0 & 0 & 0 & & \\
\hline 07/09/02 16:29 & 131 & 254 & 1 & 6 & 119 & 0 & 101 & 153 & 1683 & & 0 & 1 & & 0 & 0 & 0 & & \\
\hline 07/09/02 $16: 35$ & 137 & 255 & 1 & 11 & 119 & 0 & 102 & 153 & 1683 & & 894 & 16 & & 0 & 0 & 0 & & \\
\hline 07/09/02 $\quad 16: 39$ & 132 & 253 & 1 & 14 & 119 & 0 & 102 & 153 & 1683 & & 894 & 16 & & 0 & 0 & 0 & & \\
\hline $\begin{array}{lll}07 / 09 / 02 & 16: 44\end{array}$ & 121 & 445 & 1 & 20 & 90 & 0 & 115 & 176 & 1680 & & 897 & 3 & & 0 & 0 & 0 & & \\
\hline 07/09/02 $\quad 16: 49$ & 114 & 237 & 1 & 23 & 5 & 103 & 91 & 132 & 1572 & & & 2 & & 0 & 0 & 0 & & \\
\hline
\end{tabular}

\begin{tabular}{|c|c|c|c|c|c|c|c|c|c|c|c|c|c|c|c|c|c|c|}
\hline \multirow{3}{*}{ Date/Time } & \multicolumn{9}{|c|}{ Inlet Line To Nozzles } & \multicolumn{6}{|c|}{ Slurry Pump } & \multicolumn{3}{|c|}{ Spray Ring } \\
\hline & $\begin{array}{c}\text { PIT-PMP- } \\
12-200\end{array}$ & $\begin{array}{l}\text { FT-PMP- } \\
12-200\end{array}$ & $\begin{array}{c}\text { FET-TST- } \\
\text { 02A/B }\end{array}$ & $\begin{array}{l}\text { - FET-TST- } \\
\text { 02-Cumm }\end{array}$ & $\begin{array}{r}\text { PIT-SLC- } \\
11-202\end{array}$ & $\begin{array}{r}\text { PIT-SLC- } \\
11-203\end{array}$ & $\begin{array}{l}\text { Load- } \\
\text { PMP-301 }\end{array}$ & $\% \mathrm{~T}$ & $\begin{array}{l}\text { RPM-PMP- } \\
301\end{array}$ & $\begin{array}{l}\text { Load- } \\
\text { PMP-300 }\end{array}$ & $\begin{array}{c}\text { RPM-PMP- } \\
300\end{array}$ & $\begin{array}{l}\text { PIT-SLR- } \\
11-200\end{array}$ & $\begin{array}{c}\text { FET-TST- } \\
01 \mathrm{~A}\end{array}$ & $\begin{array}{c}\text { FET-TST- } \\
01 B\end{array}$ & $\begin{array}{l}\text { - FET-TST- } \\
\text { 1B-Cumm }\end{array}$ & $\begin{array}{l}\text { FE-To- } \\
\text { Spray } \\
\text { Ring }\end{array}$ & $\begin{array}{l}\text { FE- } \\
\text { Cumm }\end{array}$ & $\begin{array}{c}\text { PE-To- } \\
\text { Spray } \\
\text { Ring }\end{array}$ \\
\hline & (psig) & $(\mathrm{gpm})$ & (b/min) & (lbs) & (psig) & (psig) & (amps) & $(\% \mathrm{~T})$ & (rpm) & (amps) & (rpm) & (psig) & (gpm) & $(\mathrm{b} / \mathrm{min})$ & (lbs) & (gpm) & (gal) & (psig) \\
\hline $\begin{array}{lll}07 / 11 / 02 & 14: 29\end{array}$ & 0 & & 1 & 0 & 0 & 0 & 0 & 0 & 0 & & 0 & 1 & 1 & 0 & $\frac{1}{0}$ & 17.6 & 218 & 3 \\
\hline 07/11/02 $14: 43$ & 0 & 0 & 1 & 0 & 0 & 0 & 0 & 0 & 0 & & 0 & 1 & 1 & 0 & 0 & 18.6 & 371 & 1456 \\
\hline 07/11/02 14:46 & 23 & 101 & 1 & 2 & 21 & 22 & 41 & 32 & 715 & & 0 & 1 & 1 & 0 & 0 & 18.6 & 425 & 1458 \\
\hline 07/11/02 $14: 51$ & 144 & 261 & 1 & 6 & 135 & 136 & 106 & 162 & 1758 & & 1005 & 3 & 1 & 0 & 0 & 16.2 & 513 & 1458 \\
\hline 07/11/02 $15: 16$ & 0 & 0 & 1 & 8 & 0 & 0 & 0 & 0 & 0 & & 1348 & 1 & 1 & 0 & 0 & 0 & 611 & 0 \\
\hline 07/11/02 $15: 21$ & 73 & 182 & 0 & 8 & 68 & 68 & 63 & 85 & 1257 & & 1347 & 2 & 40 & & 0 & 17.3 & 659 & 1545 \\
\hline $07 / 11 / 02 \quad 15: 26$ & 132 & 251 & 0 & 74 & 124 & 125 & 99 & 149 & 1684 & & 1347 & 2 & 122 & 0 & 0 & 17.1 & 745 & 1565 \\
\hline 07/11/02 $15: 31$ & 132 & 250 & 0 & 165 & 124 & 124 & 99 & 149 & 1684 & & 1336 & 37 & 413 & 0 & 0 & 17.5 & 831 & 1531 \\
\hline 07/11/02 $15: 36$ & 132 & 250 & 44 & 316 & 123 & 124 & 99 & 150 & 1684 & & 1162 & 19 & 97 & 0 & 0 & 17.8 & 916 & 1560 \\
\hline 07/11/02 $15: 41$ & 132 & 251 & 0 & 543 & 124 & 125 & 100 & 150 & 1684 & & 1324 & 15 & 84 & 0 & 0 & 16.3 & 1002 & 1560 \\
\hline 07/11/02 $15: 46$ & 132 & 250 & 1 & 547 & 124 & 125 & 100 & 150 & 1684 & & 1023 & 9 & 277 & 0 & 0 & 0 & 1084 & 3 \\
\hline 07/11/02 $15: 51$ & 115 & 233 & 1 & 550 & 107 & 108 & 89 & 131 & 1572 & & 1021 & 7 & 112 & 0 & 0 & 0 & 1084 & 9 \\
\hline $07 / 11 / 02 \quad 15: 56$ & 86 & 204 & 1 & 554 & 80 & 80 & 73 & 101 & 1368 & & 1245 & 22 & 618 & 0 & 0 & 0 & 1084 & 3 \\
\hline 07/11/02 $16: 03$ & 1 & 0 & 1 & 559 & 1 & 0 & 0 & 0 & 0 & & 1015 & 14 & 499 & 0 & 0 & 0 & 1084 & 0 \\
\hline
\end{tabular}


Table A.2. Analytical data from the ITL Series 1 runs

\begin{tabular}{|c|cc|c|c|c|}
\hline Sample no. & Date/Time & Sample point & $\begin{array}{c}\text { Density } \\
\text { (g/mL) }\end{array}$ & $\begin{array}{c}\text { Solids } \\
\text { (wt \%) }\end{array}$ \\
\hline ITL-1A-1 & $07 / 09 / 02$ & $16: 16$ & Slurry receipt line (grab) & 1.22 & 29.1 \\
\hline ITL-1A-2 & $07 / 09 / 02$ & $16: 38$ & Slurry receipt line (grab) & 1.06 & 9.0 \\
\hline ITL-1B-1 & $07 / 11 / 02$ & $15: 25$ & Slurry receipt line (grab) & 1.04 & - \\
\hline ITL-1B-2 & $07 / 11 / 02$ & $15: 42$ & Slurry receipt line (grab) & 1.09 & - \\
\hline
\end{tabular}

\section{A.2 ITL SERIES 2 RUNS}

\section{A.2.1 Objectives}

The primary objectives of the ITL Series 2 runs were to (1) determine the effectiveness of the spray ring in forming a sump around the slurry pump with the K-65 surrogate, (2) perform an integrated test using the parameters from the ITL Series 1 runs that were most effective in mobilizing the K-65 surrogate, (3) test the operation of the Isolok samplers, (4) determine variability in system parameters (e.g., flow, pressure) during integrated testing, and (5) close the water/solids material balance during the integrated test.

\section{A.2.2 Summary of Results}

Initially, only two runs were scheduled for the ITL Series 2 tests. However, based on observations of the subsequent runs (ITL-3, -5, -6, and -7), several additional ITL-2 series runs were scheduled to test the two 280 -gal/min nozzles operating alternately.

\section{ITL Runs 2A and 2B}

- $\quad$ The operating conditions for ITL Runs ITL-2A and ITL-2B were chosen based on the results of Runs ITL-1A and ITL-1B.

- $\quad$ After Run ITL-2A, the surrogate bed was observed to be depressed in an 8- to 10-ft area around the slurry pump. However, the area just under the pump remained elevated. It was thought that the slurry operators were mining around the pump, not directly under the pump itself. The situation could not be readily corrected with the 150 -gal/min nozzles.

- $\quad$ The slurry was observed to be either flowing smoothly at full flow or not flowing at all. Pump cavitation or pulsing was not observed. The pump was either deep enough to have been primed, or it simply ran dry.

- $\quad$ ITL Runs 2C-2F (all performed with the larger-flow nozzles operated alternately) demonstrated that with the 280 -gal/min nozzles, the area under the pump could be effectively mined and a depression could be formed that could advance into a trough for the slurry pump. Based on this observation, it is recommended that two 280-gal/min nozzles operating alternately is the best configuration for silo sluicing. This nozzle configuration was chosen for Run ITL-4. Process and analytical data are provided in Tables A.3 and A.4, respectively. 


\section{Table A.3. Process data from the ITL Series 2 runs}

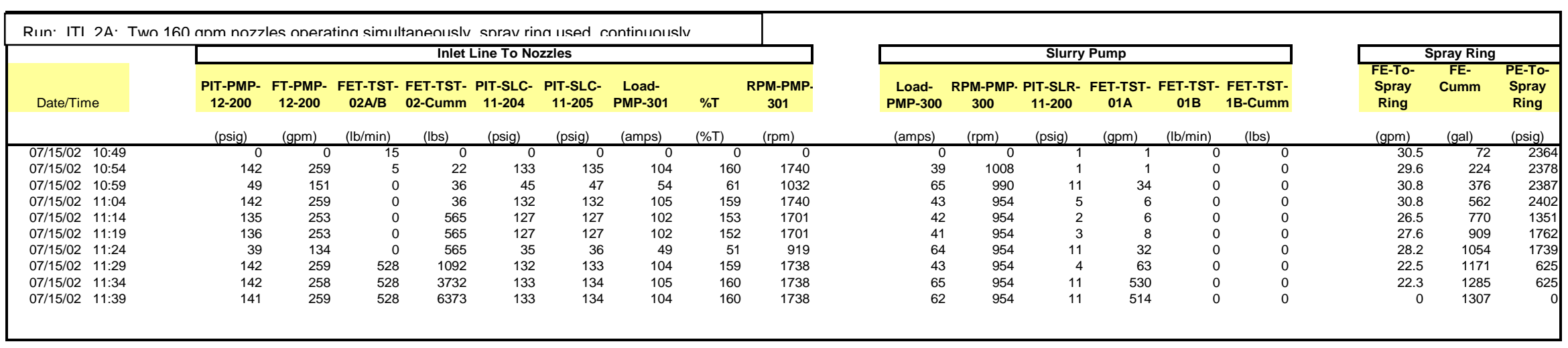

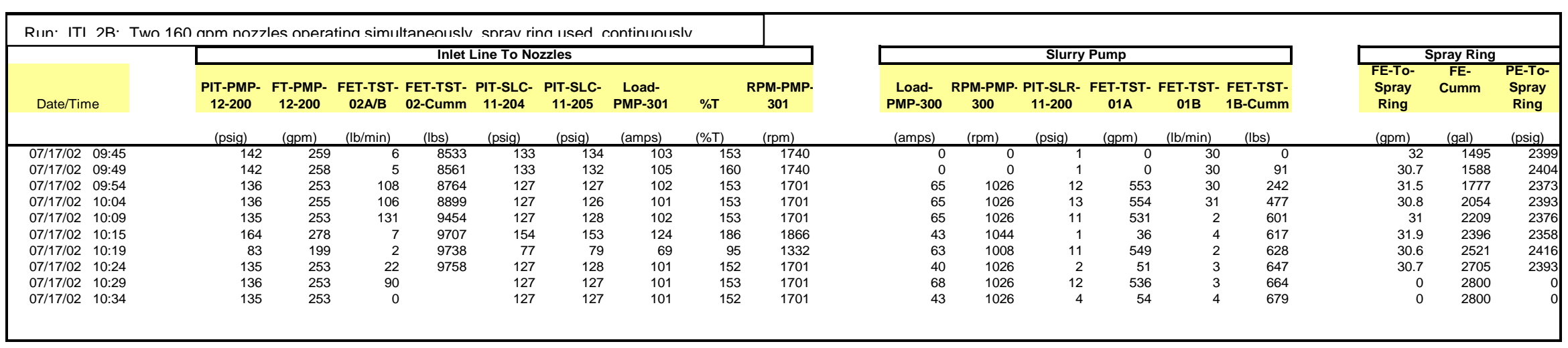

\begin{tabular}{|c|c|c|c|c|c|c|c|c|c|c|c|c|c|c|c|c|c|c|}
\hline \multirow{2}{*}{$\begin{array}{l}\text { Rın: ITI } x \text { : } \\
\text { Date/Time }\end{array}$} & \multicolumn{9}{|c|}{\begin{tabular}{|c|} 
Inlet Line To Nozzles \\
\end{tabular}} & \multicolumn{6}{|c|}{$\begin{array}{l}\text { Slurry Pump } \\
\end{array}$} & \multicolumn{2}{|c|}{ Spray Ring } & \\
\hline & $\begin{array}{l}\text { PIT-PMP- } \\
12-200\end{array}$ & $\begin{array}{c}\text { FT-PMP- } \\
12-200\end{array}$ & $\begin{array}{l}\text { FET-TST- } \\
02 \mathrm{~A} / \mathrm{B}\end{array}$ & $\begin{array}{l}\text { - FET-TST- } \\
\text { 02-Cumm }\end{array}$ & $\begin{array}{c}\text { PIT-SLC- } \\
11-204\end{array}$ & $\begin{array}{l}\text { PIT-SLC- } \\
11-205\end{array}$ & $\begin{array}{l}\text { Load- } \\
\text { PMP-301 }\end{array}$ & $\% \mathrm{~T}$ & $\begin{array}{l}\text { RPM-PMP. } \\
301\end{array}$ & $\begin{array}{l}\text { Load- } \\
\text { PMP-300 }\end{array}$ & $\begin{array}{l}\text { RPM-PMP. } \\
300\end{array}$ & $\begin{array}{l}\text { PIT-SLR- } \\
11-200\end{array}$ & $\begin{array}{l}\text { FET-TST- } \\
01 \mathrm{~A}\end{array}$ & - FET-TST- & $\begin{array}{l}\text { FET-TST- } \\
\text { 1B-Cumm }\end{array}$ & $\begin{array}{l}\text { EE-To- } \\
\text { Spray } \\
\text { Ring }\end{array}$ & $\begin{array}{l}\text { FE- } \\
\text { Cumm }\end{array}$ & $\begin{array}{l}\text { PE-To- } \\
\text { Spray } \\
\text { Ring }\end{array}$ \\
\hline & (psig) & (gpm) & $(\mathrm{b} / \mathrm{min})$ & (IDS) & (psig) & (psig) & (amps) & $(\% \mathrm{~T})$ & (rpm) & (amps) & (rpm) & (psig) & (gpm) & $(\mathrm{lb} / \mathrm{min})$ & (lbs) & (gpm) & (gal) & (psig) \\
\hline 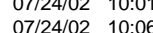 & $\begin{array}{l}150 \\
150\end{array}$ & 238 & $\begin{array}{r}0 \\
27\end{array}$ & & 0 & $\begin{array}{l}139 \\
139\end{array}$ & $\begin{array}{l}104 \\
104\end{array}$ & 158 & 1777 & 53 & 864 & 8 & 419 & $\frac{1}{2}$ & $\begin{array}{l}748 \\
757\end{array}$ & & 3365 & \\
\hline $07 / 24 / 02 \quad 10: 11$ & 147 & 237 & 71 & & 135 & 6 & 102 & 156 & 1758 & 47 & 702 & 5 & 389 & 4 & 770 & c & $\begin{array}{l}3365 \\
3365\end{array}$ & \\
\hline $07 / 24 / 02 \quad 10: 14$ & 147 & 237 & 0 & & 135 & 6 & 103 & 156 & 1758 & 46 & 702 & 5 & 112 & 4 & 777 & c & 3365 & \\
\hline $07 / 24 / 02 \quad 15: 09$ & 150 & 237 & 158 & & 0 & 137 & 104 & 158 & 1779 & 50 & 774 & 7 & 412 & 5 & 833 & c & 3365 & \\
\hline 07/24/02 $15: 12$ & 150 & 238 & 0 & & 0 & 139 & 104 & 160 & 1779 & 51 & 738 & 7 & 390 & 5 & 855 & c & 3365 & \\
\hline 07/24/02 $15: 17$ & 0 & 0 & 0 & & 0 & 0 & 0 & 0 & 0 & 0 & 0 & 1 & 0 & 0 & 860 & c & 3365 & \\
\hline
\end{tabular}


Table A.3. (Continued)

\begin{tabular}{|c|c|c|c|c|c|c|c|c|c|c|c|c|c|c|c|c|c|c|}
\hline \multirow{2}{*}{ Date/Time } & \multicolumn{9}{|c|}{$\begin{array}{l}\text { Inlet Line To Nozzles } \\
\end{array}$} & \multicolumn{6}{|c|}{ Slurry Pump } & \multicolumn{3}{|c|}{ Spray Ring } \\
\hline & $\begin{array}{l}\text { PIT-PMP- } \\
12-200\end{array}$ & $\begin{array}{c}\text { FT-PMP- } \\
12-200\end{array}$ & $\begin{array}{c}\text { FET-TST- } \\
02 A / B\end{array}$ & $\begin{array}{l}\text { FET-TST- } \\
\text { 02-Cumm }\end{array}$ & $\begin{array}{c}\text { PIT-SLC- } \\
11-204\end{array}$ & $\begin{array}{l}\text { PIT-SLC- } \\
11-205\end{array}$ & $\begin{array}{l}\text { Load- } \\
\text { PMP-301 }\end{array}$ & $\% \mathrm{~T}$ & $\begin{array}{l}\text { RPM-PMP. } \\
\quad 301\end{array}$ & $\begin{array}{l}\text { Load- } \\
\text { PMP-300 }\end{array}$ & $\begin{array}{l}\text { RPM-PMP. } \\
\quad 300\end{array}$ & $\begin{array}{l}\text { PIT-SLR- } \\
11-200\end{array}$ & $\begin{array}{c}\text { FET-TST- } \\
01 \mathrm{~A}\end{array}$ & $\begin{array}{c}\text { - FET-TST- } \\
01 \mathrm{~B}\end{array}$ & $\begin{array}{l}\text { FET-TST- } \\
\text { 1B-Cumm }\end{array}$ & $\begin{array}{l}\text { FE-To- } \\
\text { Spray } \\
\text { Ring }\end{array}$ & $\begin{array}{l}\mathrm{FE}- \\
\text { Cumm }\end{array}$ & $\begin{array}{l}\text { PE-To- } \\
\text { Spray } \\
\text { Ring }\end{array}$ \\
\hline & (psig) & (gpm) & $(\mathrm{b} / \mathrm{min})$ & (lbs) & (psig) & (psig) & (amps) & $(\% \mathrm{~T})$ & $(\mathrm{rpm})$ & (amps) & $(\mathrm{rpm})$ & (psig) & $(\mathrm{gpm})$ & $(\mathrm{b} / \mathrm{min})$ & (lbs) & $(\mathrm{gpm})$ & (gal) & (psig) \\
\hline $\begin{array}{ll}08 / 05 / 02 & 10: 47\end{array}$ & 143 & 264 & 1 & & 128 & & 99 & 151 & 1740 & 0 & 0 & 1 & 1 & 10 & 902 & 32.6 & 6376 & 2283 \\
\hline 08/05/02 $10: 52$ & 142 & 265 & 0 & & 128 & & 102 & 154 & 1740 & 40 & 972 & 1 & 1 & 1 & 901 & 31.7 & 6536 & 2289 \\
\hline 08/05/02 $10: 56$ & 16 & 59 & 15 & & 3 & & 42 & 33 & 655 & 42 & 972 & 3 & 37 & 7 & 901 & 33.5 & 6699 & 2347 \\
\hline 08/05/02 11:02 & 137 & 257 & 0 & & 5 & & 98 & 147 & 1702 & 41 & 936 & 3 & 77 & 7 & 904 & 28.1 & 6861 & 1345 \\
\hline 08/05/02 $11: 07$ & 134 & 254 & 131 & & 5 & & 95 & 143 & 1684 & 52 & 810 & 7 & 449 & 9 & 908 & 26.7 & 6999 & 1146 \\
\hline 08/05/02 $\quad 11: 12$ & 134 & 253 & 124 & & 5 & & 96 & 144 & 1684 & 51 & 792 & 7 & 418 & 8 & 913 & 31.3 & 7140 & 2173 \\
\hline 08/05/02 $11: 17$ & 143 & 259 & 0 & & 128 & & 101 & 151 & 1740 & 40 & 792 & 1 & 59 & 9 & 918 & 30.9 & 7295 & 2199 \\
\hline 08/05/02 $11: 22$ & 43 & 161 & 81 & & 39 & & 46 & 44 & 915 & 50 & 792 & 7 & 417 & 7 & 925 & 32 & 7455 & 2173 \\
\hline 08/05/02 $11: 27$ & 0 & 2 & 62 & & -2 & & 0 & 0 & 0 & 63 & 1026 & 12 & 544 & 4 & 926 & 30.5 & 7611 & 2187 \\
\hline
\end{tabular}

\begin{tabular}{|c|c|c|c|c|c|c|c|c|c|c|c|c|c|c|c|c|c|c|c|}
\hline \multirow{2}{*}{\multicolumn{2}{|c|}{ Date/Time }} & \multicolumn{9}{|c|}{ Inlet Line To Nozzles } & \multicolumn{6}{|c|}{ Slurry Pump } & \multicolumn{3}{|c|}{ Spray Ring } \\
\hline & & $\begin{array}{l}\text { PIT-PMP- } \\
12-200\end{array}$ & $\begin{array}{c}\text { FT-PMP- } \\
12-200\end{array}$ & $\begin{array}{l}\text { FET-TST- } \\
02 \mathrm{~A} / \mathrm{B}\end{array}$ & $\begin{array}{l}\text { FET-TST- } \\
\text { 02-Cumm }\end{array}$ & $\begin{array}{c}\text { PIT-SLC- } \\
11-204\end{array}$ & $\begin{array}{l}\text { PIT-SLC- } \\
11-205\end{array}$ & $\begin{array}{l}\text { Load- } \\
\text { PMP-301 }\end{array}$ & $\% \mathrm{~T}$ & $\begin{array}{c}\text { RPM-PMP. } \\
301\end{array}$ & $\begin{array}{l}\text { Load- } \\
\text { PMP-300 }\end{array}$ & $\begin{array}{c}\text { RPM-PMP } \\
300\end{array}$ & $\begin{array}{l}\text { PIT-SLR- } \\
11-200\end{array}$ & $\begin{array}{c}\text { FET-TST- } \\
01 \mathrm{~A}\end{array}$ & $\begin{array}{c}\text { FET-TST- } \\
01 B\end{array}$ & $\begin{array}{l}\text { FET-TST- } \\
\text { 1B-Cumm }\end{array}$ & $\begin{array}{l}\text { Spray } \\
\text { Ring }\end{array}$ & $\begin{array}{l}\text { Cumm } \\
\text { Cu- }\end{array}$ & Rpray \\
\hline & & (psig) & (gpm) & $(\mathrm{b} / \mathrm{min})$ & (lbs) & (psig) & (psig) & (amps) & $(\% \mathrm{~T})$ & (rpm) & (amps) & (rpm) & (psig) & (gpm) & $(\mathrm{b} / \mathrm{min})$ & (lbs) & $(\mathrm{gpm})$ & (gal) & (psig) \\
\hline $08 / 09 / 02 \quad 10$ & 10:46 & 146 & 262 & $\begin{array}{ll}2 & 1 \\
\end{array}$ & & 137 & 138 & 100 & 152 & 1758 & 0 & 0 & 1 & 0 & 0 & 977 & 34.6 & 9142 & 2286 \\
\hline $08 / 09 / 02 \quad 10$ & 10:50 & 146 & 262 & 0 & & 137 & & 102 & 156 & 1758 & 42 & 936 & 4 & 52 & 0 & 975 & 34.2 & 9275 & 2292 \\
\hline 08/09/02 10 & 10:52 & 146 & 252 & 0 & 0 & 137 & 136 & 103 & 156 & 1758 & 43 & 936 & 1 & 80 & 0 & 973 & 33.6 & 9340 & 2271 \\
\hline $08 / 09 / 02 \quad 10$ & 10:53 & 146 & 262 & 0 & 0 & 137 & & 104 & 156 & 1758 & 41 & 936 & 3 & 69 & 0 & 973 & 33.7 & 9373 & 2306 \\
\hline $08 / 09 / 02 \quad 10$ & 10:54 & 146 & 262 & 0 & 0 & 136 & & 103 & 155 & 1758 & 42 & 936 & 3 & 74 & 0 & 972 & 34.5 & 9405 & 2283 \\
\hline $08 / 09 / 02 \quad 10$ & 10:56 & 145 & 262 & 0 & b & 136 & & 103 & 156 & 1726 & 41 & 936 & 3 & 75 & 0 & 970 & 33.2 & 9474 & 2292 \\
\hline $08 / 09 / 02 \quad 10$ & 10:58 & 146 & 262 & 0 & D & 136 & & 103 & 157 & 1758 & 60 & 936 & 12 & 454 & 0 & 968 & 33.9 & 9542 & 2274 \\
\hline $08 / 09 / 02 \quad 10$ & 10:59 & 146 & 262 & 129 & & 136 & & 103 & 156 & 1758 & 56 & 900 & 10 & 470 & 0 & 965 & 32.7 & 9575 & 2292 \\
\hline 08/09/02 11 & 11:00 & 145 & 262 & 81 & & 136 & & 103 & 154 & 1758 & 48 & 882 & 3 & 242 & 0 & 964 & 33.1 & 9609 & 2312 \\
\hline 08/09/02 11 & $11: 01$ & 146 & 262 & 0 & 5 & 136 & 137 & 104 & 155 & 1758 & 56 & 882 & 10 & 453 & 0 & 962 & 32.7 & 9642 & 2257 \\
\hline 08/09/02 11 & 11:03 & 143 & 259 & 95 & & 134 & & 101 & 154 & 1740 & 56 & 882 & 9 & 470 & 0 & 958 & 32.7 & 9708 & 2268 \\
\hline 08/09/02 11 & 11:05 & 143 & 259 & 135 & & 134 & & 102 & 155 & 1740 & 56 & 882 & 9 & 471 & 0 & 954 & 34.4 & 9775 & 2300 \\
\hline 08/09/02 11 & 11:08 & 143 & 259 & 137 & & 134 & & 102 & 153 & 1740 & 57 & 882 & 9 & 469 & 0 & 946 & 32.3 & 9877 & 2306 \\
\hline $08 / 09 / 02 \quad 11$ & 11:10 & 143 & 259 & 0 & 0 & 134 & & 101 & 156 & 1740 & 55 & 882 & 9 & 429 & 0 & 941 & 34.2 & 9944 & 2300 \\
\hline 08/09/02 11 & $11: 11$ & 143 & 259 & 0 & b & 134 & 134 & 101 & 153 & 1740 & 56 & 882 & 9 & 473 & 0 & 938 & 33.4 & 9978 & 2297 \\
\hline 08/09/02 11 & 11:12 & 143 & 259 & & 0 & 134 & & 102 & 154 & 1740 & 40 & 882 & 3 & 84 & 0 & 935 & 33.9 & 10011 & 2300 \\
\hline 08/09/02 11 & 11:13 & 2 & 39 & 0 & 0 & 1 & & 0 & 0 & 0 & 54 & 882 & 9 & 471 & 0 & 932 & 33.3 & 10046 & 2297 \\
\hline 08/09/02 11 & 11:14 & 0 & 0 & 0 & 0 & 0 & & 0 & 0 & 0 & 55 & 882 & 9 & 474 & 0 & 932 & 29.5 & 10075 & 1464 \\
\hline $\begin{array}{ll}08 / 09 / 02 & 11\end{array}$ & $11: 16$ & 0 & 0 & 0 & 0 & 0 & & 0 & 0 & 0 & 54 & 882 & 8 & 475 & 0 & 933 & 28.7 & 10135 & 1421 \\
\hline 08/09/02 11 & 11:17 & 0 & 0 & 0 & 0 & 0 & & 0 & 0 & 0 & 46 & 882 & 4 & 330 & 0 & 933 & 30 & 10164 & 1435 \\
\hline
\end{tabular}


Table A.4. Analytical data from the ITL Series 2 runs

\begin{tabular}{|c|c|c|c|c|}
\hline Sample no. & Date/Time & Sample point & $\begin{array}{l}\text { Density } \\
\text { (g/mL) }\end{array}$ & $\begin{array}{c}\text { Solids } \\
\text { (wt \%) }\end{array}$ \\
\hline ITL-2A-Grab-11:13 & 07/15/02 11:13 & Slurry receipt line (grab) & 1.31 & 36.8 \\
\hline ITL-2A-Grab-11:21 & 07/15/02 11:21 & Slurry receipt line (grab) & 1.23 & 28.4 \\
\hline ITL-2A-Sluice & 07/15/02 11:21 & ISS-TST-001(composite) & 1.00 & 0.004 \\
\hline ITL-2A-Slurry & 07/15/02 11:21 & ISS-TST-002 (composite) & 1.18 & 30.4 \\
\hline ITL-2B-Grab-10:05 & 07/17/02 10:05 & Slurry receipt line (grab) & 1.13 & 17.1 \\
\hline ITL-2B-Grab-10:23 & 07/17/02 10:23 & Slurry receipt line (grab) & 1.11 & 17.4 \\
\hline ITL-2B-Grab-10:34 & 07/17/02 $10: 34$ & Slurry receipt line (grab) & 1.25 & 31.7 \\
\hline ITL-2B-Sluice & 07/17/02 09:43 & ISS-TST-001(composite) & 1.00 & 0.006 \\
\hline ITL-2B-Slurry & 07/17/02 09:43 & ISS-TST-002 (composite) & 1.09 & 14.1 \\
\hline ITL-2C-Grab-10:10 & 07/24/02 10:10 & Slurry receipt line (grab) & 1.03 & 5.6 \\
\hline ITL-2C-Grab-15:12 & 07/24/02 15:12 & Slurry receipt line (grab) & 1.65 & 30.3 \\
\hline ITL-2C-Slurry & 07/24/02 15:12 & ISS-TST-002 (composite) & 1.09 & 17.5 \\
\hline ITL-2E-Grab-11:07 & 08/05/02 11:07 & Slurry receipt line (grab) & 1.11 & 14.8 \\
\hline ITL-2E-Grab-11:21 & 08/05/02 11:21 & Slurry receipt line (grab) & 1.09 & 14.1 \\
\hline ITL-2E-Slurry & 08/05/02 11:10 & Slurry receipt line (grab) & 1.00 & 15.0 \\
\hline ITL-2E-Sluice & 08/05/02 11:10 & ISS-TST-001(composite) & 0.94 & 0.0055 \\
\hline ITL1-2F-Slurry & 08/09/02 11:00 & ISS-TST-002 (composite) & 1.05 & 13.9 \\
\hline ITL1-2F-Grab1 & 08/09/02 11:02 & Slurry receipt line (grab) & 1.15 & 21.5 \\
\hline ITL1-2F-Grab2 & 08/09/02 11:10 & Slurry receipt line (grab) & 1.07 & 12.9 \\
\hline
\end{tabular}




\section{A.3 ITL SERIES 3 RUNS}

\section{A.3.1 Objectives}

The primary objective of the Series 3 runs was to determine the effects of reduced flow on the slurry pump. The pump flow was decreased in 50-gal/min ( 400-lb/min) increments from an initial setting of $350 \mathrm{gal} / \mathrm{min}(\sim 3000 \mathrm{lb} / \mathrm{min})$ to a minimum of $200 \mathrm{gal} / \mathrm{min}(\sim 1700 \mathrm{lb} / \mathrm{min})$, and the effectiveness of the pump in handling the slurries was noted. After each reduction, the system was allowed to reach steady-state operation, and data were taken before the next flow reduction was made. Operating personnel noted any visible differences in the effectiveness of the pump in handling the slurry at the reduced flows during the integrated tests.

\section{A.3.2 Summary of Results}

Run ITL-3 demonstrated that there does appear to be a relationship between flow and electrical load to the pump (see Fig. A.6). This relationship could prove of value during full-scale silo operation. However, the load/flow relationship will need to be determined during start-up of the AWR system (as installed) to account for system pressure drop and desired operating pump speed. Process and analytical data are provided in Tables A.5 and A.6, respectively.

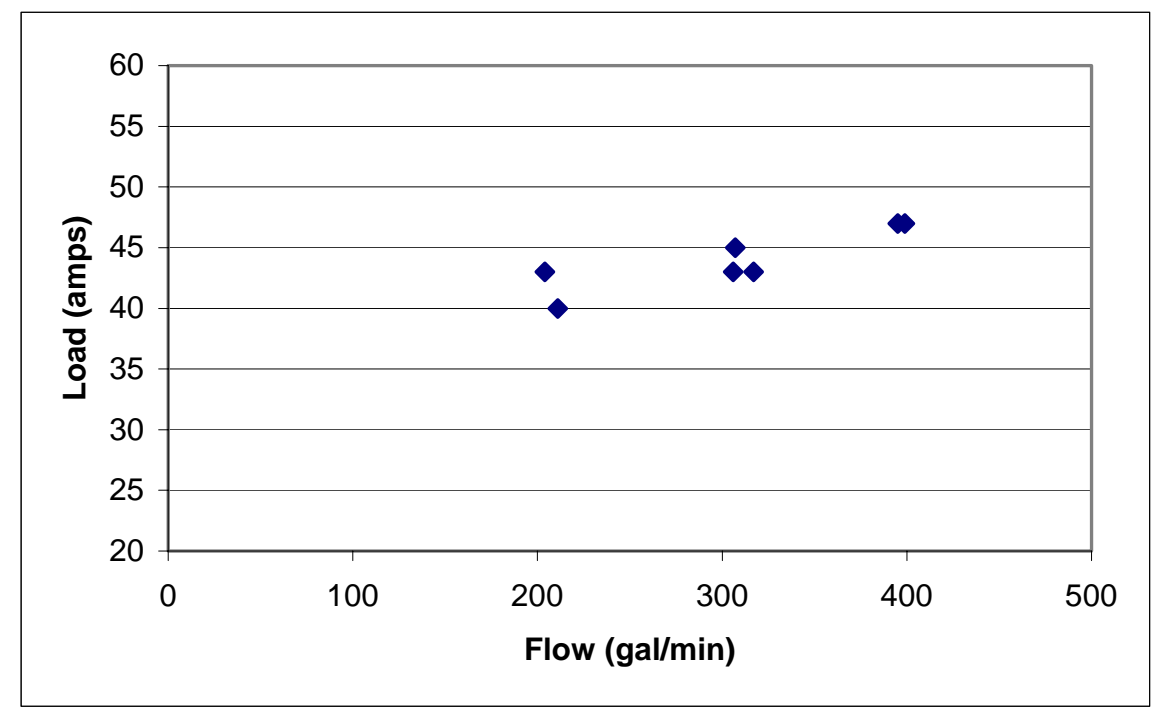

Fig. A.6. Pump load as a function of flow at approximately $670 \mathrm{rpm}$. 
Table A.5 Process data from the ITL Series 3 runs

\begin{tabular}{|c|c|c|c|c|c|c|c|c|c|c|c|c|c|c|c|c|c|c|}
\hline \multicolumn{16}{|c|}{ Run: ITL-3: Two $150 \mathrm{~g}$ nozzles operating simultaneously, spray ring used continuously. } & & & \\
\hline \multirow{3}{*}{ Date/Time } & \multicolumn{9}{|c|}{ Inlet Line To Nozzles } & \multicolumn{6}{|c|}{ Slurry Pump } & \multicolumn{3}{|c|}{ Spray Ring } \\
\hline & $\begin{array}{c}\text { PIT-PMP- } \\
12-200\end{array}$ & $\begin{array}{c}\text { FT-PMP. } \\
12-200\end{array}$ & $\begin{array}{c}\text { FET-TST- } \\
02 \mathrm{~A} / \mathrm{B}\end{array}$ & $\begin{array}{l}\text { - FET-TST- } \\
\text { 02-Cumm }\end{array}$ & $\begin{array}{c}\text { PIT-SLC- } \\
11-204\end{array}$ & $\begin{array}{l}\text { PIT-SLC- } \\
11-205\end{array}$ & $\begin{array}{l}\text { Load- } \\
\text { PMP-301 }\end{array}$ & $\% \mathrm{~T}$ & $\begin{array}{l}\text { RPM-PMP. } \\
301\end{array}$ & $\begin{array}{l}\text { Load- } \\
\text { PMP-300 }\end{array}$ & $\begin{array}{l}\text { RPM-PMP. } \\
300\end{array}$ & $\begin{array}{c}\text { PIT-SLR- } \\
11-200\end{array}$ & $\begin{array}{c}\text { FET-TST- } \\
01 \mathrm{~A}\end{array}$ & $\begin{array}{c}\text { - FET-TST- } \\
01 B\end{array}$ & $\begin{array}{l}\text { FET-TST- } \\
\text { 1B-Cumm }\end{array}$ & Spray & Cumm & $\begin{array}{l}\text { PE-10- } \\
\text { Spray } \\
\text { Ring }\end{array}$ \\
\hline & (psig) & (gpm) & $(\mathrm{lb} / \mathrm{min})$ & (lbs) & (psig) & (psig) & (amps) & $(\% \mathrm{~T})$ & $(\mathrm{rpm})$ & (amps) & $(\mathrm{rpm})$ & (psig) & (gpm) & $(\mathrm{b} / \mathrm{min})$ & (lbs) & (gpm) & (gal) & (psig) \\
\hline $\begin{array}{lll}07 / 19 / 02 & 11: 58\end{array}$ & 145 & 262 & 1 & $\overline{1}$ & 136 & 136 & 105 & 159 & 1758 & 0 & 0 & 1 & 0 & 0 & 693 & 26 & 2817 & 1319 \\
\hline 07/19/02 12:03 & 139 & 256 & 1 & 1 & 130 & 131 & 102 & 155 & 1720 & 39 & 882 & 1 & 1 & 1 & 694 & 30.8 & 2971 & 2494 \\
\hline 07/19/02 $12: 05$ & 139 & 256 & 1 & 1 & 130 & 130 & 102 & 154 & 1716 & 0 & 0 & 0 & -1 & 1 & 695 & 30.1 & 3035 & 2448 \\
\hline 07/19/02 $\quad 12: 08$ & 139 & 257 & 40 & & 130 & & 102 & 155 & 1720 & 40 & 738 & 1 & 211 & 1 & 696 & 33.4 & 3130 & 2465 \\
\hline 07/19/02 $\quad 12: 12$ & 139 & 257 & 56 & & 130 & 132 & 102 & 155 & 1720 & 47 & 738 & 6 & 395 & 1 & 699 & 32.1 & 3258 & 2451 \\
\hline 07/19/02 $\quad 12: 13$ & 57 & 178 & 61 & & 52 & & 54 & 59 & 1059 & 47 & 738 & 6 & 399 & 0 & 699 & 32.2 & 3290 & 2471 \\
\hline 07/19/02 $12: 18$ & 18 & 86 & 23 & & 15 & 16 & 40 & 25 & 621 & 43 & 576 & 4 & 306 & 0 & 698 & 0 & 3353 & 0 \\
\hline 07/19/02 $12: 23$ & 139 & 256 & 1 & 1 & 130 & 129 & 101 & 156 & 1720 & 40 & 576 & 1 & 1 & 1 & 699 & 0 & 3365 & 0 \\
\hline 07/19/02 $\quad 12: 28$ & 139 & 256 & 1 & 1 & 130 & 131 & 102 & 154 & 1720 & 41 & 576 & 1 & 10 & 1 & 703 & 0 & 3365 & 3 \\
\hline $07 / 19 / 02 \quad 12: 34$ & 49 & 152 & 35 & & 45 & 47 & 52 & 60 & 1032 & 45 & 576 & 4 & 307 & 0 & 706 & 0 & 3365 & 3 \\
\hline 07/19/02 $\quad 12: 38$ & 50 & 152 & 25 & & 45 & 47 & 51 & 59 & 1033 & 43 & 396 & 2 & 204 & 0 & 705 & 0 & 3365 & 0 \\
\hline 07/19/02 $\quad 12: 43$ & 142 & 259 & 11 & & 133 & 134 & 103 & 156 & 1740 & 40 & 612 & 1 & 72 & 1 & 705 & 0 & 3365 & -3 \\
\hline $07 / 19 / 02 \quad 12: 48$ & 46 & 146 & 23 & & 41 & 43 & 51 & 55 & 996 & 43 & 612 & 5 & 317 & 0 & 706 & 0 & 3365 & -3 \\
\hline
\end{tabular}

Table A.6. Analytical data from the ITL Series 3 Runs

\begin{tabular}{|l|ll|c|c|c|}
\hline \multicolumn{1}{|c|}{ Sample no. } & \multicolumn{2}{|c|}{ Date/Time } & Sample point & Density (g/mL) & Solids (wt \%) \\
\hline ITL-3-Sluice & $07 / 19 / 02$ & $12: 05$ & ISS-TST-001 (composite) & 1.00 & 0.0053 \\
\hline ITL-3-Slurry & $07 / 19 / 02$ & $12: 05$ & ISS-TST-002 (composite) & 1.02 & 1.04 \\
\hline ITL-3-Grab:12:13 & $07 / 19 / 02$ & $12: 13$ & Slurry Receipt Line (grab) & 1.02 & 2.4 \\
\hline ITL-3-Grab:12:15 & $07 / 19 / 02$ & $12: 15$ & Slurry Receipt Line (grab) & 1.04 & 6.2 \\
\hline ITL-3-Grab:12:35 & $07 / 19 / 02$ & $12: 35$ & Slurry Receipt Line (grab) & 1.01 & 3.2 \\
\hline ITL-3-Grab:12:41 & $07 / 19 / 02$ & $12: 41$ & Slurry Receipt Line (grab) & \\
\hline
\end{tabular}




\section{A.4 ITL Series 4 Run}

\section{A.4.1 Objectives}

A Bentogrout cap was placed over the K-65 surrogate in the surrogate material tank for the ITL Series 4 runs to simulate the Bentogrout cap in the silos. The K-65/Bentogrout ratio in the surrogate material tank was similar to that found in the top $15 \mathrm{ft}$ of the silos. To simulate the actual conditions of the solids in the silos, the cap will vary from $\sim 1 \mathrm{ft}$ thick at the rounded end of the Tank to a few inches thick under the pump. The manufacturer's recommendations were followed to form a hard Bentogrout crust prior to starting the ITL Series 4 runs. The primary objectives of this series of runs were to (1) determine if the nozzle and pump configurations that proved effective in mobilizing the K-65 surrogate are effective in mobilizing the K65/Bentogrout combination, (2) determine if the nozzle and pump configurations that proved effective in mobilizing the K-65 surrogate are effective in breaking up the Bentogrout cap, (3) verify the operation of the mass flowmeters and Isolok samplers on the K-65/Bentogrout combination, (4) determine the density and percent solids handled by the slurry pump during an integrated run with the K-65/Bentogrout combination from composite samples taken over the entire duration of the runs, (5) close the solids/water material balance for the Series 4 runs, and (6) verify the load on the slurry pump while operating with the K-65/Bentogrout combination.

\section{A.4.2 Summary of Results}

The Bentogrout cap was added to the surrogate tank the week of August 12, 2002. First, most of the free water was removed from the surface of the surrogate tank. Then, Bentogrout was mixed in the approximate proportion of $50 \mathrm{lbs}$ of dry Bentogrout material to 14 gal of water. The Bentogrout mixture was then pumped onto the surface of the surrogate tank and allowed to cure for approximately 3 days. Also, a 2- to 3-ft mound of surrogate was placed under the pump and covered with Bentogrout to simulate the actual surface topography of the silos. Figure A.7 is a photograph of the surrogate tank surface prior to initiating Run ITL-4.

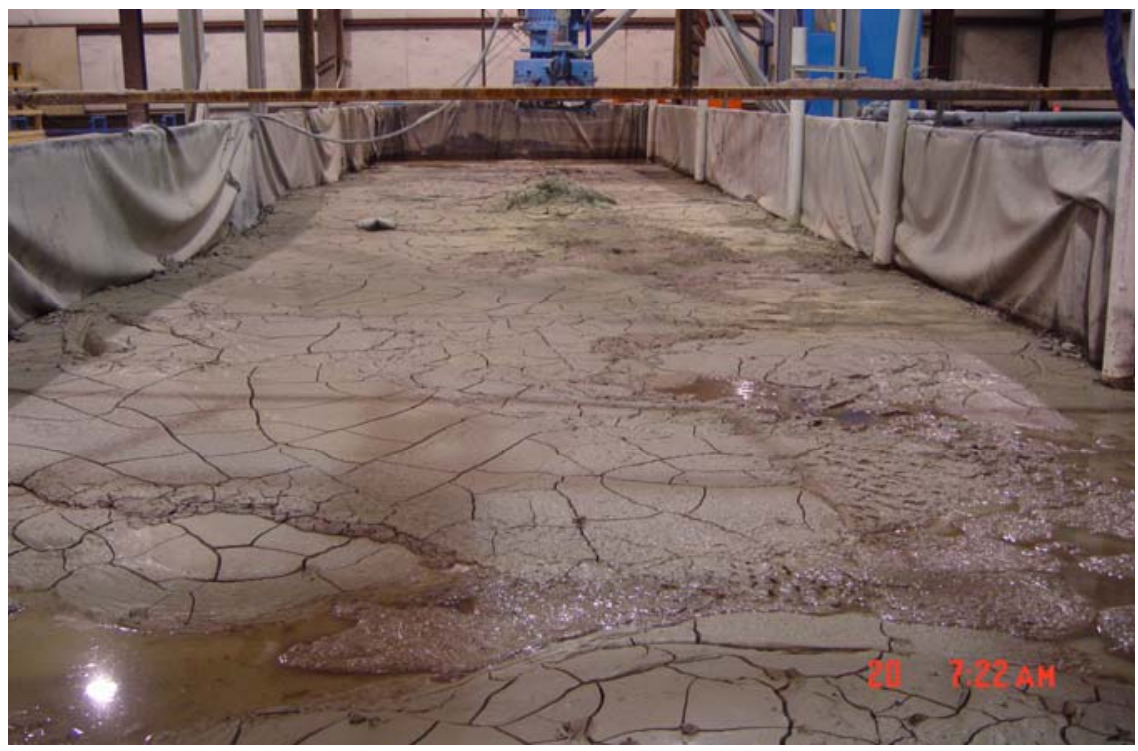

Fig. A.7. Surrogate tank covered with Bentogrout prior to Run ITL-4. 
As described in the results of the ITL Series 2 Runs, the nozzle configuration chosen was to run two 280-gal/min (15/16-in.) nozzles operated alternately. Run ITL-4 was initiated by lowering the pump to within a few feet of the surrogate surface, starting the spray nozzles at a supply pressure of approximately 2300 psi, and observing the effect on the mound of surrogate under the pump. The spray nozzles appeared to readily cut through the Bentogrout cap.

The sluice water flow was then started and almost immediately cut through the Bentogrout cap and mobilized it to the sluice pump, demonstrating that this configuration should be very effective in handling the Bentogrout cap in the AWR application.

Most of the Bentogrout material in close proximity to the pump was removed in this one test (see Fig. A.8).

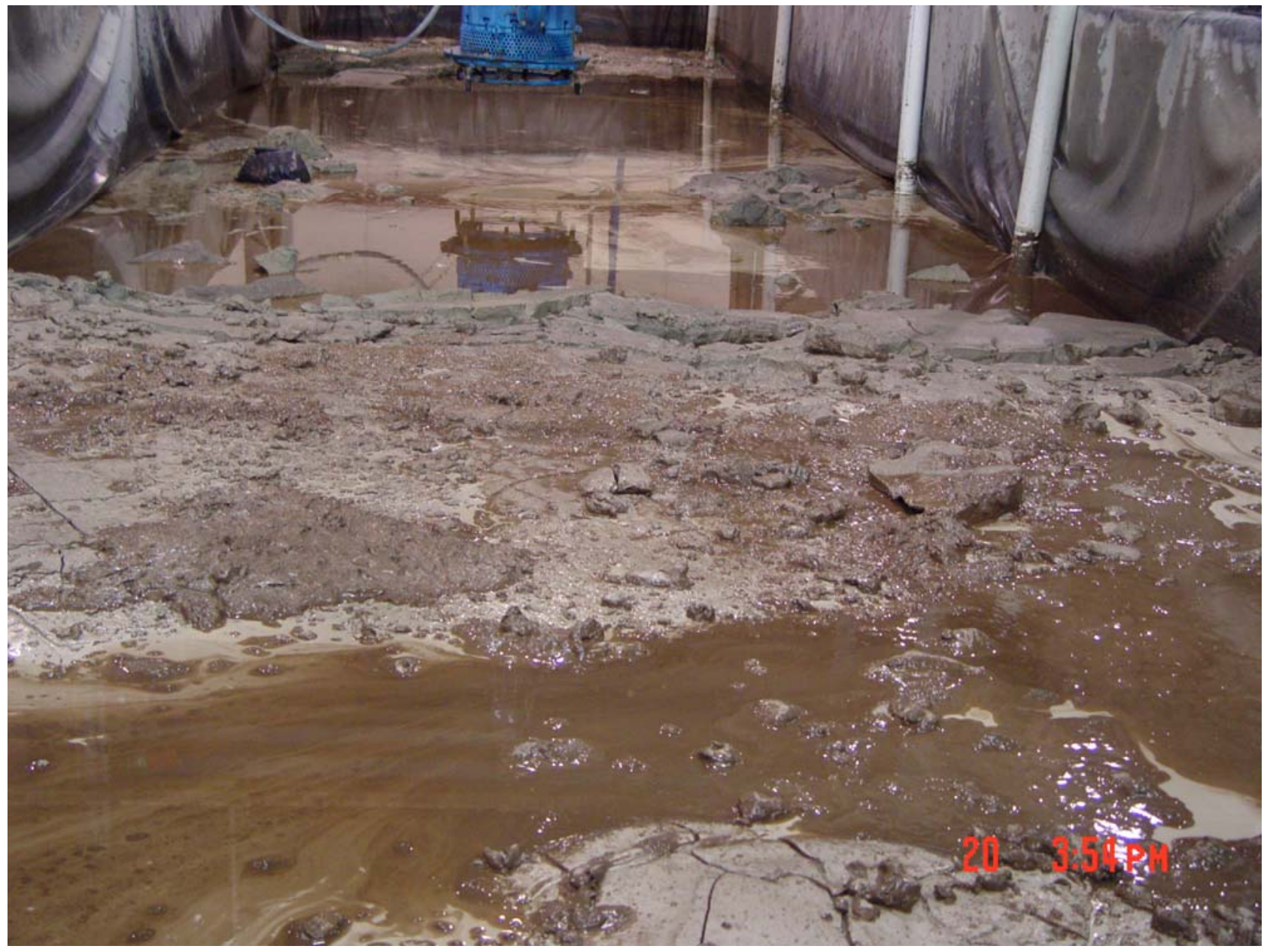

Fig. A.8. Surrogate tank covered with Bentogrout after to Run ITL-4.

One other major observation was noted during this test. The pump screen appeared to blind (see Fig. 4.3 in the body of this report). During the test, the slurry flow unexpectedly decreased and did not recover when by the pump speed was changed. The pump was lifted from below the water surface, and the screen appeared to be blinded with surrogate. The surrogate was readily removed with the sluice water flow. Process and analytical data are provided in Tables A.7 and A.8, respectively. 
Table A.7. Process data from the ITL Series 4 runs

\begin{tabular}{|c|c|c|c|c|c|c|c|c|c|c|c|c|c|c|c|c|c|c|}
\hline \multirow{3}{*}{ Date/Time } & \multicolumn{9}{|c|}{ Inlet Line To Nozzles } & \multicolumn{6}{|c|}{ Slurry Pump } & \multicolumn{3}{|c|}{ Spray Ring } \\
\hline & $\begin{array}{c}\text { PIT-PMP- } \\
12-200\end{array}$ & $\begin{array}{r}\text { FT-PMP- } \\
12-200\end{array}$ & $\begin{array}{c}\text { FET-TST- } \\
02 A / B\end{array}$ & $\begin{array}{l}\text { FET-TST- } \\
02 \text {-Cumm }\end{array}$ & $\begin{array}{c}\text { PIT-SLC- } \\
11-204\end{array}$ & $\begin{array}{l}\text { PIT-SLC- } \\
11-205\end{array}$ & $\begin{array}{l}\text { Load- } \\
\text { PMP-301 }\end{array}$ & $\% \mathrm{~T}$ & $\begin{array}{c}\text { RPM-PMP. } \\
301\end{array}$ & $\begin{array}{l}\text { Load- } \\
\text { PMP-300 }\end{array}$ & $\begin{array}{l}\text { RPM-PMP. } \\
\quad 300\end{array}$ & $\begin{array}{c}\text { PIT-SLR- } \\
11-200\end{array}$ & $\begin{array}{c}\text { FET-TST- } \\
01 \mathrm{~A}\end{array}$ & $\begin{array}{c}\text { FET-TST- } \\
01 \mathrm{~B}\end{array}$ & $\begin{array}{l}\text { - FET-TST- } \\
\text { 1B-Cumm }\end{array}$ & $\begin{array}{l}\text { Spray } \\
\text { Ring }\end{array}$ & Cumm & $\begin{array}{l}\text { Spray } \\
\text { Ring }\end{array}$ \\
\hline & (psig) & (gpm) & $(\mathrm{lb} / \mathrm{min})$ & (lbs) & (psig) & (psig) & (amps) & $(\% \mathrm{~T})$ & $(\mathrm{rpm})$ & (amps) & (rpm) & (psig) & (gpm) & $(\mathrm{lb} / \mathrm{min})$ & (lbs) & (gpm) & (gal) & (psig) \\
\hline 08/20/02 $14: 30$ & 146 & 266 & $\begin{array}{ll}6 & 1\end{array}$ & 1 & 0 & 132 & 101 & 152 & 1758 & 0 & 0 & 2 & 0 & 0 & 934 & 30.9 & 10336 & 2271 \\
\hline 08/20/02 14:35 & 146 & 266 & 6 & ) & 0 & 132 & 104 & 155 & 1758 & 41 & 882 & 3 & 94 & 0 & 928 & 32.3 & 10494 & 2312 \\
\hline 08/20/02 14:38 & 146 & 266 & 6 & ) & 0 & 132 & 103 & 155 & 1758 & 56 & 828 & 10 & 398 & 0 & 921 & 30.5 & 10593 & 2283 \\
\hline 08/20/02 14:40 & 104 & 207 & 7 & ) & 92 & 5 & 84 & 123 & 1524 & 55 & 846 & 10 & 426 & 0 & 917 & 32.4 & 10655 & 2289 \\
\hline 08/20/02 14:46 & 143 & 265 & 5 & ) & 129 & 5 & 101 & 153 & 1740 & 56 & 846 & 10 & 403 & 0 & 904 & 32.6 & 10844 & 2292 \\
\hline 08/20/02 14:50 & 143 & 265 & 5 & & 129 & 6 & 102 & 153 & 1740 & 56 & 846 & 9 & 419 & 0 & 896 & 30.8 & 10970 & 2283 \\
\hline 08/20/02 14:55 & 22 & 116 & 6 & & 18 & 5 & 40 & 22 & 627 & 56 & 846 & 9 & 434 & 0 & 887 & 31.8 & 11124 & 2315 \\
\hline 08/20/02 15:01 & 134 & 254 & 0 & & 4 & 121 & 96 & 143 & 1684 & 40 & 846 & 1 & 47 & 0 & 877 & 0 & 11247 & 0 \\
\hline 08/20/02 15:06 & 146 & 266 & 0 & D & 4 & 132 & 103 & 156 & 1758 & 59 & 990 & 7 & 369 & 0 & 870 & 30 & 11334 & 2043 \\
\hline 08/20/02 15:11 & 146 & 266 & 6 & & 4 & 133 & 101 & 154 & 1758 & 57 & 990 & 7 & 376 & 0 & 864 & 30.1 & 11484 & 2043 \\
\hline 08/20/02 15:15 & 0 & 0 & 97 & & 4 & 1 & 0 & 0 & 0 & 56 & 990 & 7 & 384 & 1 & 858 & 28.5 & 11599 & 1664 \\
\hline 08/20/02 $15: 20$ & 0 & 0 & 67 & & 4 & 0 & 0 & 0 & 0 & 63 & 1116 & 8 & 428 & 1 & 861 & 26.9 & 11737 & 1319 \\
\hline
\end{tabular}

Table A.8. Analytical data from the ITL Series 4 runs

\begin{tabular}{|l|c|c|c|c|}
\hline \multicolumn{1}{|c|}{ Sample no. } & Date/Time & Sample point & Density (g/mL) & Solids (wt \%) \\
\hline ITL4-Slurry & $8 / 20 / 200214: 20$ & Slurry receipt line (grab) & 1.16 & 26.0 \\
\hline ITL4-Grab-14:34 & $8 / 20 / 200214: 34$ & Slurry receipt line (grab) & 1.32 & 39.8 \\
\hline ITL4-Grab-14:49 & $8 / 20 / 200214: 49$ & Slurry receipt line (grab) & 1.29 & 37.1 \\
\hline ITL4-Grab-14:56 & $8 / 20 / 200214: 56$ & Slurry receipt line (grab) & 1.23 & 32.3 \\
\hline
\end{tabular}




\section{A.5 ITL SERIES 5 RUNS}

\section{A.5.1 Objectives}

The primary objective of the Series 5 run was to determine operational parameters typical of what would happen if the line on the discharge of the slurry pump becomes partially or fully blocked. In this test, VLV-TST-01 was closed in increments, the ITL system allowed to reach steady state, and the process parameters determined at each of the valve VLV-TST-01 positions.

\section{A.5.2 Summary of Results}

The Series 5 ITL run was conducted in conjunction with the ITL Series 7A run. Therefore, no process and analytical data for the ITL Series 5 runs are included here. The data for this series are included in the ITL Series 7A run data (see Sect. A.7).

\section{A.6 ITL SERIES 6 RUNS}

\section{A.6.1 Objectives}

The primary objective of the ITL Series 6 runs was to determine if the pump can handle debris that might be located in the site and that cannot be removed by long-handled tools.

\section{A.6.2 Summary of Results}

The debris added to the system included angle iron, a cinder block, plastic gloves, several sample bottles, a two-by-four, and a plastic bag of debris (see Fig. A.9). The results of the runs were uneventful. The debris could be easily manipulated with the spray nozzles and kept away from the slurry pump. The Hazelton representative did have a concern with the agitator potentially becoming entangled with a glove or piece of wire and recommended operating without the agitator. Process and analytical data are provided in Tables A.9 and A.10, respectively.

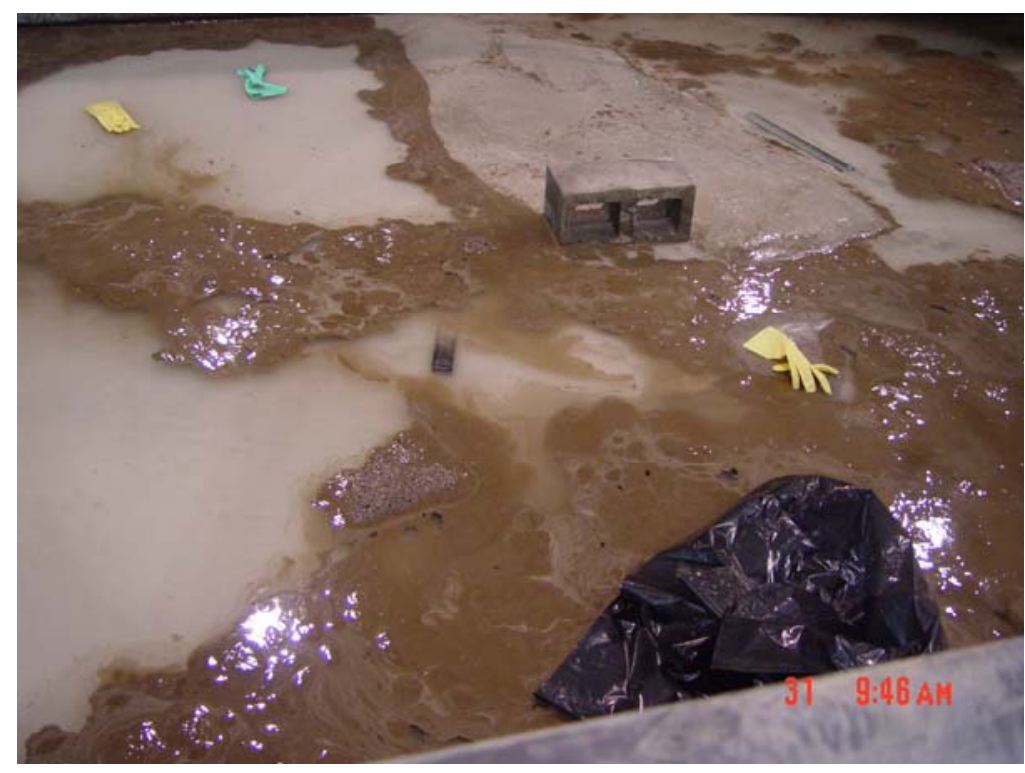

Fig. A.9. Debris added to the surrogate tank for Run ITL-6. 
Table A.9. Process data from the ITL Series 6 runs

\begin{tabular}{|c|c|c|c|c|c|c|c|c|c|c|c|c|c|c|c|c|c|c|}
\hline \multirow{3}{*}{ Date/Time } & \multicolumn{9}{|c|}{ Inlet Line To Nozzles } & \multicolumn{6}{|c|}{ Slurry Pump } & \multicolumn{3}{|c|}{ Spray Ring } \\
\hline & $\begin{array}{l}\text { PIT-PMP- } \\
12-200\end{array}$ & $\begin{array}{c}\text { FT-PMP- } \\
12-200\end{array}$ & $\begin{array}{c}\text { FET-TST- } \\
02 \mathrm{~A} / \mathrm{B}\end{array}$ & $\begin{array}{l}\text { FET-TST- } \\
02 \text {-Cumm }\end{array}$ & $\begin{array}{l}\text { PIT-SLC- } \\
11-204\end{array}$ & $\begin{array}{c}\text { PIT-SLC- } \\
11-205\end{array}$ & $\begin{array}{l}\text { Load- } \\
\text { PMP-301 }\end{array}$ & $\% \mathrm{~T}$ & $\begin{array}{c}\text { RPM-PMP. } \\
301\end{array}$ & $\begin{array}{l}\text { Load- } \\
\text { PMP-300 }\end{array}$ & $\begin{array}{l}\text { RPM-PMP. } \\
300\end{array}$ & $\begin{array}{l}\text { PIT-SLR- } \\
11-200\end{array}$ & $\begin{array}{c}\text { - FET-TST- } \\
01 \mathrm{~A}\end{array}$ & $\begin{array}{c}\text { FET-TST- } \\
01 \mathrm{~B}\end{array}$ & $\begin{array}{l}\text { FET-TST- } \\
\text { 1B-Cumm }\end{array}$ & $\begin{array}{l}\text { Spray } \\
\text { Ring }\end{array}$ & Cumm & $\begin{array}{l}\text { Spray } \\
\text { Ring }\end{array}$ \\
\hline & (psig) & (gpm) & $(\mathrm{b} / \mathrm{min})$ & (lbs) & (psig) & (psig) & (amps) & $(\% \mathrm{~T})$ & $(\mathrm{rpm})$ & (amps) & $(\mathrm{rpm})$ & (psig) & (gpm) & $(\mathrm{lb} / \mathrm{min})$ & (lbs) & $(\mathrm{gpm})$ & (gal) & (psig) \\
\hline $\begin{array}{ll}07 / 31 / 02 & 10: 19\end{array}$ & 145 & 265 & 5 & $\overline{0}$ & 0 & 130 & 103 & 156 & 1758 & 0 & 0 & 1 & 0 & $\frac{2}{2}$ & 882 & 33.7 & 5249 & 2297 \\
\hline $07 / 31 / 02 \quad 10: 24$ & 142 & 262 & 0 & 0 & 0 & 128 & 103 & 154 & 1740 & 50 & 756 & 8 & 400 & 1 & 887 & 34.4 & 5416 & 2303 \\
\hline $07 / 31 / 02 \quad 10: 29$ & 142 & 262 & 0 & & 0 & 129 & 103 & 155 & 1740 & 40 & 756 & 1 & 60 & 2 & 893 & 34.7 & 5586 & 2283 \\
\hline 08/01/02 $10: 34$ & 142 & 264 & 0 & 0 & 128 & 6 & 102 & 153 & 1740 & 40 & 756 & 0 & 40 & 2 & 900 & 34.9 & 5765 & 2277 \\
\hline $\begin{array}{ll}07 / 31 / 02 & 10: 39\end{array}$ & 142 & 264 & 0 & & 128 & 6 & 102 & 154 & 1740 & 49 & 756 & 7 & 395 & 2 & 909 & 33.9 & 5942 & 2300 \\
\hline
\end{tabular}

\begin{tabular}{|c|c|c|c|c|c|c|c|c|c|c|c|c|c|c|c|c|c|c|}
\hline \multirow[b]{2}{*}{ Date/Time } & \multicolumn{9}{|c|}{ Inlet Line To Nozzles } & \multicolumn{6}{|c|}{ Slurry Pump } & \multicolumn{3}{|c|}{ Spray Ring } \\
\hline & $\begin{array}{l}\text { PIT-PMP- } \\
12-200\end{array}$ & $\begin{array}{l}\text { FT-PMP- } \\
12-200\end{array}$ & $\begin{array}{c}\text { FET-TST- } \\
02 A / B\end{array}$ & $\begin{array}{l}\text { - FET-TST- } \\
02 \text {-Cumm }\end{array}$ & $\begin{array}{l}\text { PIT-SLC- } \\
11-204\end{array}$ & $\begin{array}{l}\text { PIT-SLC- } \\
11-205\end{array}$ & $\begin{array}{l}\text { Load- } \\
\text { PMP-301 }\end{array}$ & $\% \mathrm{~T}$ & $\begin{array}{l}\text { RPM-PMP. } \\
301\end{array}$ & $\begin{array}{l}\text { Load- } \\
\text { PMP-300 }\end{array}$ & $\begin{array}{l}\text { RPM-PMP. } \\
300\end{array}$ & $\begin{array}{l}\text { D. PIT-SLR- } \\
11-200\end{array}$ & $\begin{array}{c}\text { FET-TST- } \\
01 \mathrm{~A}\end{array}$ & $\begin{array}{c}\text { FET-TST- } \\
01 \mathrm{~B}\end{array}$ & $\begin{array}{l}\text { FET-TST- } \\
\text { 1B-Cumm }\end{array}$ & $\begin{array}{l}\text { FE-To- } \\
\text { Spray } \\
\text { Ring }\end{array}$ & $\begin{array}{l}\text { FE- } \\
\text { Cumm }\end{array}$ & $\begin{array}{l}\text { PE-To- } \\
\text { Spray } \\
\text { Ring }\end{array}$ \\
\hline $\begin{array}{lll}08 / 07 / 02 & 09: 17\end{array}$ & 0 & 0 & 1 & $\overline{1}$ & 0 & & 0 & 0 & 0 & 0 & 0 & 1 & 1 & 0 & 928 & 30.1 & 7814 & 2225 \\
\hline 08/07/02 $09: 20$ & 145 & 268 & 1 & 1 & 131 & & 101 & 153 & 1758 & 0 & 0 & 1 & 0 & 1 & 928 & 30.7 & 7908 & 2240 \\
\hline 08/07/02 $09: 24$ & 145 & 268 & 1 & 1 & 131 & & 103 & 151 & 1758 & 0 & 0 & 1 & 0 & 0 & 928 & 29.9 & 8034 & 2260 \\
\hline 08/07/02 $\quad 09: 25$ & 145 & 267 & 1 & 1 & 131 & & 104 & 157 & 1755 & 0 & 0 & 1 & 1 & 1 & 928 & 30 & 8065 & 2274 \\
\hline $\begin{array}{ll}08 / 07 / 02 & 09: 26\end{array}$ & 145 & 267 & 4 & 4 & 131 & & 103 & 157 & 1758 & 43 & 936 & 3 & 21 & 0 & 928 & 32.4 & 8097 & 2277 \\
\hline $\begin{array}{ll}08 / 07 / 02 & 09: 27\end{array}$ & 145 & 267 & 0 & 0 & 131 & & 104 & 156 & 1758 & 44 & 936 & 3 & 53 & 1 & 928 & 31 & 8129 & 2277 \\
\hline 08/07/02 $09: 30$ & 145 & 267 & 19 & & 131 & & 103 & 157 & 1758 & 41 & 936 & 2 & 75 & 1 & 930 & 31.4 & 8223 & 2260 \\
\hline 08/07/02 $09: 31$ & 145 & 267 & 21 & & 131 & & 104 & 157 & 1758 & 40 & 936 & 1 & 86 & & 931 & 30.7 & 8254 & 2271 \\
\hline 08/07/02 $09: 32$ & 145 & 267 & 18 & & 131 & & 103 & 157 & 1758 & 41 & 936 & 1 & 91 & 1 & 932 & 31 & 8286 & 2286 \\
\hline 08/07/02 $09: 34$ & 145 & 267 & 0 & & 130 & & 103 & 156 & 1758 & 51 & 810 & 8 & 430 & 2 & 935 & 30.3 & 8349 & 2271 \\
\hline 08/07/02 $09: 35$ & 145 & 267 & 0 & & 130 & & 103 & 159 & 1758 & 49 & 792 & 8 & 406 & 2 & 937 & 31.5 & 8380 & 2283 \\
\hline 08/07/02 $09: 36$ & 145 & 267 & 0 & & 130 & & 103 & 159 & 1758 & 50 & 792 & 8 & 398 & 2 & 939 & 31.7 & 8412 & 2303 \\
\hline 08/07/02 $09: 37$ & 7 & 83 & 69 & & 5 & & 39 & 11 & 376 & 50 & 792 & 8 & 421 & & 941 & 31.9 & 8443 & 2315 \\
\hline 08/07/02 $09: 38$ & 107 & 208 & 52 & & 4 & & 80 & 121 & 1531 & 50 & 792 & 7 & 424 & 1 & 942 & 31.6 & 8475 & 2260 \\
\hline 08/07/02 $09: 39$ & 145 & 265 & 88 & & 5 & & 103 & 155 & 1758 & 49 & 756 & 7 & 403 & & 944 & 30.5 & 8507 & 2268 \\
\hline 08/07/02 $\quad 09: 40$ & 145 & 265 & 79 & & 5 & & 102 & 156 & 1758 & 49 & 756 & 7 & 397 & & 946 & 31.7 & 8537 & 2286 \\
\hline 08/07/02 $\quad 09: 42$ & 145 & 265 & 0 & & 5 & & 103 & 155 & 1758 & 49 & 756 & 7 & 362 & 2 & 951 & 31.8 & 8601 & 2286 \\
\hline $\begin{array}{ll}08 / 07 / 02 & 09: 44\end{array}$ & 145 & 264 & 142 & & 5 & & 103 & 156 & 1758 & 49 & 756 & 7 & 402 & & 957 & 30.8 & 8663 & 2303 \\
\hline 08/07/02 $09: 45$ & 145 & 265 & 118 & & 5 & & 102 & 155 & 1758 & 49 & 756 & 7 & 403 & & 960 & 30.9 & 8694 & 2303 \\
\hline 08/07/02 $\quad 09: 46$ & 145 & 265 & 170 & & 5 & & 103 & 156 & 1758 & 49 & 756 & 7 & 395 & 3 & 963 & 32 & 8725 & 2283 \\
\hline 08/07/02 $\quad 09: 47$ & 12 & 84 & 128 & & 5 & & 39 & 13 & 462 & 50 & 756 & 7 & 404 & 1 & 966 & 30.6 & 8756 & 2289 \\
\hline 08/07/02 09:52 & 108 & 229 & 244 & & 97 & & 80 & 116 & 1516 & 50 & 756 & 8 & 394 & 2 & 976 & 31.3 & 8941 & 2292 \\
\hline 08/07/02 $\quad 09: 53$ & 108 & 229 & 272 & & 97 & & 80 & 116 & 1516 & 51 & 756 & 8 & 393 & 2 & 976 & 30.7 & 8941 & 2254 \\
\hline 08/07/02 $09: 54$ & 0 & 0 & 341 & & 0 & & 0 & 0 & 0 & 50 & 756 & 8 & 381 & 0 & 977 & 26.7 & 8968 & 1453 \\
\hline
\end{tabular}


Table A.10. Analytical data from the ITL Series 6 runs

\begin{tabular}{|l|ll|l|c|c|}
\hline \multicolumn{1}{|c|}{ Sample no. } & \multicolumn{2}{|c|}{ Date/Time } & Sample point & $\begin{array}{c}\text { Density } \\
\mathbf{( g / m L )}\end{array}$ & $\begin{array}{c}\text { Solids } \\
\mathbf{( w t} \mathbf{~ \% )}\end{array}$ \\
\hline ITL-6-Grab-10:25 & $07 / 31 / 02$ & $10: 25$ & Slurry receipt line (grab) & 1.13 & 13.8 \\
\hline ITL-6-Grab-10:40 & $07 / 31 / 02$ & $10: 40$ & Slurry receipt line (grab) & 1.06 & 11.0 \\
\hline ITL-6-Sluice & $07 / 31 / 02$ & $10: 20$ & ISS-TST-001 (composite) & 0.92 & 0.0009 \\
\hline ITL-6-Slurry & $07 / 31 / 02$ & $10: 20$ & ISS-TST-002 (composite) & 1.04 & 16.3 \\
\hline ITE-6B-Grab-9:39 & $08 / 07 / 02$ & $09: 39$ & Slurry receipt line (grab) & 1.14 & 19.0 \\
\hline ITE-6B-Grab-9:50 & $08 / 07 / 02$ & $09: 50$ & Slurry receipt line (grab) & 1.17 & 23.1 \\
\hline ITE-6B-Sluice & $08 / 07 / 02$ & $09: 40$ & ISS-TST-001 (composite) & 0.95 & 0.0007 \\
\hline ITE-6B-Slurry & $08 / 07 / 02$ & $09: 40$ & Slurry receipt line (grab) & 1.09 & 16.0 \\
\hline
\end{tabular}

\section{A.7 ITL SERIES 7 RUNS}

\section{A.7.1 Objectives}

The primary objective of the Series 7 runs was to cut the power to the ITL system during operation and determine how the system reacts to restarting after an uncontrolled shutdown. Two shutdowns were performed. The first was conducted after the ITL Series 5 runs, while the system contained K-65 surrogate only. The second shutdown was conducted after the ITL Series 4 runs, while the system contained a combination of K-65 surrogate and Bentogrout.

\section{A.7.2 Summary of Results}

In these runs, the system was operated to a point where the slurry flow was fully established (300-450 gal/min). In the case of Run ITL-5, the discharge valves to the collections were then incrementally closed. In the case of Runs ITL-7A and B, the slurry and sluice pumps were then stopped and the system allowed to sit idle for $15 \mathrm{~min}$. These runs were noneventful. In the case of ITL Runs-7A and B, the system restarted immediately and no plugging or other problems were observed. In Run ITL-5, the discharge valve was slowly closed and other than a corresponding decrease in flow and an increase in discharge pressure, there were no other remarkable observations. Process and analytical data are provided in Tables A.11 and A.12, respectively. 
Table A.11. Process data from the ITL Series 7 runs

\begin{tabular}{|c|c|c|c|c|c|c|c|c|c|c|c|c|c|c|c|c|c|c|}
\hline \multirow[b]{2}{*}{ Date/Time } & \multicolumn{9}{|c|}{ Inlet Line To Nozzles } & \multicolumn{6}{|c|}{ Slurry Pump } & \multicolumn{3}{|c|}{ Spray Ring } \\
\hline & $\begin{array}{c}\text { PIT-PMP- } \\
12-200\end{array}$ & $\begin{array}{c}\text { FT-PMP. } \\
12-200\end{array}$ & $\begin{array}{c}\text { FET-TST- } \\
\text { 02A/B }\end{array}$ & $\begin{array}{l}\text { FET-TST- } \\
\text { 02-Cumm }\end{array}$ & $\begin{array}{l}\text { PIT-SLC- } \\
11-204\end{array}$ & $\begin{array}{l}\text { PIT-SLC- } \\
11-205\end{array}$ & $\begin{array}{l}\text { Load- } \\
\text { PMP-301 }\end{array}$ & $\% \mathrm{~T}$ & $\begin{array}{c}\text { RPM-PMP. } \\
301\end{array}$ & $\begin{array}{l}\text { Load- } \\
\text { PMP-300 }\end{array}$ & $\begin{array}{c}\text { RPM-PMP } \\
300\end{array}$ & $\begin{array}{l}\text { PIT-SLR- } \\
11-200\end{array}$ & $\begin{array}{l}\text { - FET-TST- } \\
01 \mathrm{~A}\end{array}$ & $\begin{array}{c}\text { - FET-TST } \\
01 \mathrm{~B}\end{array}$ & $\begin{array}{l}\text { T- FET-TST- } \\
\text { 1B-Cumm }\end{array}$ & $\begin{array}{l}\text { Spray } \\
\text { Ring }\end{array}$ & Cumm & $\begin{array}{l}\text { Spray } \\
\text { Ring }\end{array}$ \\
\hline & (psig) & (gpm) & $(\mathrm{b} / \mathrm{min})$ & (lbs) & (psig) & (psig) & (amps) & $(\% \mathrm{~T})$ & (rpm) & (amps) & (rpm) & (psig) & (gpm) & $(\mathrm{b} / \mathrm{min})$ & (lbs) & (gpm) & (gal) & (psig) \\
\hline $\begin{array}{ll}07 / 22 / 02 & 10: 03\end{array}$ & 150 & 238 & 1 & & 0 & & 104 & 157 & 1777 & 0 & 0 & 1 & 0 & & 708 & 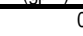 & 3365 & \\
\hline 07/22/02 $\quad 10: 06$ & 50 & 134 & 1 & & 0 & 46 & 51 & 58 & 1033 & 0 & 0 & 1 & 1 & & 708 & 0 & 3365 & \\
\hline 07/22/02 $\quad 10: 11$ & 150 & 238 & 25 & & 0 & 139 & 105 & 159 & 1777 & 48 & 756 & 6 & 405 & & 712 & 0 & 3365 & \\
\hline 07/22/02 $\quad 10: 11$ & 150 & 238 & 27 & & 0 & 139 & 104 & 160 & 1777 & 47 & 756 & & 405 & & 712 & 0 & 3365 & \\
\hline 07/22/02 $\quad 10: 11$ & 94 & 202 & 111 & & 0 & 139 & 74 & 99 & 1405 & 46 & 0 & 1 & 337 & & 712 & 0 & 3365 & \\
\hline $07 / 22 / 02 \quad 10: 26$ & 0 & 1 & 1 & & 0 & 139 & 53 & 4 & 136 & 0 & 0 & & 0 & & 712 & 0 & 3365 & \\
\hline $\begin{array}{ll}07 / 22 / 02 & 10: 27\end{array}$ & 150 & 238 & 43 & & 0 & 139 & 101 & 154 & 1755 & 48 & 756 & 7 & 178 & & 712 & c & 3365 & \\
\hline $07 / 22 / 02 \quad 10: 29$ & 150 & 238 & 0 & 0 & 0 & 139 & 102 & 156 & 1777 & 40 & 756 & 0 & 253 & & 713 & 0 & 3365 & \\
\hline $07 / 22 / 02 \quad 10: 36$ & 150 & 239 & 60 & & 138 & & 103 & 158 & 1777 & 49 & 756 & & 406 & & 722 & 0 & 3365 & \\
\hline $07 / 22 / 02 \quad 10: 36$ & 150 & 240 & 63 & & 138 & & 103 & 156 & 1777 & 46 & 666 & 5 & 356 & & 724 & 0 & 3365 & \\
\hline $07 / 22 / 02 \quad 10: 38$ & 150 & 239 & 157 & & 138 & & 106 & 159 & 1777 & 48 & 666 & 6 & 352 & & 728 & 0 & 3365 & \\
\hline $07 / 22 / 02 \quad 10: 41$ & 150 & 239 & 38 & & 138 & & 105 & 159 & 1777 & 43 & 666 & 11 & 124 & & 732 & 0 & 3365 & \\
\hline $07 / 22 / 02 \quad 10: 42$ & 150 & 239 & 1 & 1 & 138 & & 106 & 161 & 1777 & 43 & 666 & 12 & 1 & & 737 & 0 & 3365 & \\
\hline $07 / 22 / 02 \quad 10: 46$ & 150 & 239 & 108 & & 138 & & 105 & 160 & 1777 & 51 & 828 & 8 & 436 & & 741 & 0 & 3365 & \\
\hline $07 / 22 / 02 \quad 10: 51$ & 0 & 0 & 72 & 2 & 0 & 0 & 0 & 0 & 0 & 53 & 864 & 9 & 458 & & 744 & 0 & 3365 & \\
\hline
\end{tabular}

\begin{tabular}{|c|c|c|c|c|c|c|c|c|c|c|c|c|c|c|c|c|c|c|}
\hline \multirow{3}{*}{ Date/Time } & \multicolumn{9}{|c|}{ Inlet Line To Nozzles } & \multicolumn{6}{|c|}{ Slurry Pump } & \multicolumn{3}{|c|}{ Spray Ring } \\
\hline & $\begin{array}{c}\text { PIT-PMP. } \\
12-200\end{array}$ & $\begin{array}{l}\text { FT-PMP- } \\
12-200\end{array}$ & $\begin{array}{l}\text { FET-TST. } \\
\text { 02A/B }\end{array}$ & $\begin{array}{l}\text { - FET-TST- } \\
\text { 02-Cumm }\end{array}$ & $\begin{array}{c}\text { PIT-SLC- } \\
11-204\end{array}$ & $\begin{array}{l}\text { PIT-SLC- } \\
\text { 11-205 }\end{array}$ & $\begin{array}{l}\text { Load- } \\
\text { PMP-301 }\end{array}$ & $\% \mathrm{~T}$ & $\begin{array}{c}\text { RPM-PMP. } \\
301\end{array}$ & $\begin{array}{l}\text { Load- } \\
\text { PMP-300 }\end{array}$ & $\begin{array}{l}\text { RPM-PMP. } \\
300\end{array}$ & $\begin{array}{c}\text { PIT-SLR- } \\
11-200\end{array}$ & $\begin{array}{l}\text { FET-TST- } \\
01 \mathrm{~A}\end{array}$ & $\begin{array}{c}\text { FET-TST- } \\
01 \mathrm{~B}\end{array}$ & $\begin{array}{l}\text { FET-TST- } \\
\text { 1B-CUmm }\end{array}$ & $\begin{array}{l}\text { Spray } \\
\text { Ring }\end{array}$ & Cumm & $\begin{array}{l}\text { Spray } \\
\text { Ring }\end{array}$ \\
\hline & (psig) & $(\mathrm{gpm})$ & $(\mathrm{b} / \mathrm{min})$ & (bs) & (psig) & (psig) & (amps) & $(\% \mathrm{~T})$ & $(\mathrm{rpm})$ & (amps) & $(\mathrm{rpm})$ & (psig) & $(\mathrm{gpm})$ & $(\mathrm{b} / \mathrm{min})$ & (bs) & $(\mathrm{gpm})$ & (gal) & (psig) \\
\hline $\begin{array}{lll}08 / 22 / 02 & 14: 21\end{array}$ & 147 & 268 & $8 \quad 0$ & - & 132 & & 101 & 153 & 1758 & 45 & 1044 & 2 & 84 & 31 & 897 & 32.3 & 11950 & 2306 \\
\hline 08/22/02 $14: 22$ & 147 & 268 & 35 & & 132 & & 102 & 156 & 1758 & 44 & 1044 & 2 & 111 & 23 & 927 & 31.9 & 11982 & 2268 \\
\hline 08/22/02 $14: 28$ & 2 & 34 & 8 & & 1 & 132 & 39 & 19 & 312 & 40 & 1044 & 1 & 36 & 1 & 1123 & 31.4 & 12174 & 2283 \\
\hline 08/22/02 $14: 31$ & 149 & 265 & 4 & 4 & 5 & 132 & 104 & 159 & 1758 & 41 & 1044 & 1 & 25 & 65 & 1255 & 33.4 & 12267 & 2292 \\
\hline 08/22/02 $14: 33$ & 149 & 265 & 5 & 5 & 4 & 132 & 105 & 159 & 1758 & 41 & 1224 & 2 & 33 & 73 & 1391 & 30.7 & 12332 & 2277 \\
\hline 08/22/02 $14: 44$ & 0 & 0 & 1 & & 4 & & 0 & 0 & 0 & 0 & 0 & 1 & 0 & 0 & 1753 & 0 & 12576 & \\
\hline 08/22/02 $14: 47$ & 149 & 264 & 59 & & 4 & 132 & 103 & 156 & 1758 & 48 & 1044 & 3 & 237 & 86 & 1794 & 29.8 & 12609 & 1664 \\
\hline 08/22/02 $14: 48$ & 149 & 264 & 0 & & 4 & 132 & 104 & 153 & 1758 & 56 & 1170 & 5 & 256 & 85 & 1879 & 29.5 & 12638 & 1649 \\
\hline $08 / 22 / 02 \quad 14: 50$ & 149 & 265 & 0 & D & 4 & 132 & 104 & 159 & 1758 & 54 & 1170 & 4 & 253 & 85 & 2048 & 29.4 & 12696 & 1655 \\
\hline $08 / 22 / 02 \quad 14: 52$ & 149 & 265 & 5 & D & 4 & 132 & 106 & 160 & 1758 & 53 & 1368 & 3 & 220 & 87 & 2220 & 29.6 & 12755 & 1675 \\
\hline 08/22/02 $15: 11$ & & & & & & & & & & 60 & 1134 & 5 & 348 & & & & & \\
\hline 08/22/02 $\quad 15: 15$ & & & & & & & & & & 60 & 1134 & 5 & 355 & & & & & \\
\hline 08/22/02 $15: 16$ & & & & & & & & & & 0 & 0 & 0 & 0 & & & & & \\
\hline 08/22/02 $\quad 15: 19$ & & & & & & & & & & 63 & 1134 & 7 & 404 & & & & & \\
\hline $\begin{array}{lll}08 / 22 / 02 & 15: 21\end{array}$ & & & & & & & & & & 0 & 0 & 0 & 0 & & & & & \\
\hline
\end{tabular}


Table A.12. Analytical data from the ITL Series 7 runs

\begin{tabular}{|c|c|c|c|c|}
\hline Sample no. & Date/Time & Sample point & $\begin{array}{l}\text { Density } \\
\text { (g/mL) }\end{array}$ & $\begin{array}{l}\text { Solids } \\
\text { (wt \%) }\end{array}$ \\
\hline ITL-7A-Sluice & 07/22/02 10:00 & ISS-TST-001 (composite) & 0.98 & 0.0018 \\
\hline ITL-7A-Slurry & 07/22/02 10:00 & ISS-TST-002 (composite) & 1.04 & 6.4 \\
\hline ITL-7A-Grab-10:30 & 07/22/02 $10: 30$ & Slurry receipt line (grab) & 1.07 & 9.2 \\
\hline ITL-7A-Grab-10:36 & 07/22/02 $10: 36$ & Slurry receipt line (grab) & 1.08 & 12.3 \\
\hline ITL-7A-Grab-10:50 & 07/22/02 $10: 50$ & Slurry receipt line (grab) & 1.01 & 2.2 \\
\hline
\end{tabular}





\section{INTERNAL DISTRIBUTION}

1. J. N. Herndon

2. R. T. Jubin

3. B. E Lewis

4. C. P. McGinnis

5. J. F. Walker, Jr.

6. Laboratory Records-RC

7. Central Research Laboratory

\section{EXTERNAL DISTRIBUTION}

8. T. J. Abraham, The Providence Group Applied Technology, Inc.

9. N. Akgunduz, U.S. DOE

10. L. Bounini, Duratek Federal Services, Inc.

11. J. Bradburn, Fluor Fernald, Inc.

12. G. Chamberlain, U.S. DOE

13. L. Cox, Jacobs Engineering, Inc.

14. R. Fellman, Fluor Fernald, Inc.

15. J. Hughes, Fluor Fernald, Inc.

16. M. Jensen, University of North Dakota

17. M. Lamon, Jocobs Engineering, Inc.

18. J. North, Duratek Federal Services, Inc.

19. P. Pettit, Fluor Fernald, Inc. 